Research Article

\title{
Does Industrial Agglomeration Promote Carbon Efficiency? A Spatial Econometric Analysis and Fractional-Order Grey Forecasting
}

\author{
Zuoren Sun $\left.{ }^{1}\right)^{1}$ and Yi Liu $\mathbb{D i D}^{1,2}$ \\ ${ }^{1}$ Business School, Shandong University, No. 180 West of Wenhua Road, Weihai, Shandong 264209, China \\ ${ }^{2}$ Tianjin Central Sub-branch, The People's Bank of China, Economic and Technological Development Zone, \\ No. 59 East of Xincheng Road, Tianjin 300450, China
}

Correspondence should be addressed to Zuoren Sun; sunzuoren@sdu.edu.cn

Received 11 June 2021; Accepted 17 July 2021; Published 31 July 2021

Academic Editor: Lifeng Wu

Copyright (c) 2021 Zuoren Sun and Yi Liu. This is an open access article distributed under the Creative Commons Attribution License, which permits unrestricted use, distribution, and reproduction in any medium, provided the original work is properly cited.

\begin{abstract}
In theory, the industrial agglomeration is a double-edged sword as there are both positive and negative externalities. China's cities, with great disparities on degrees of the industrial agglomeration, often face different energy and carbon dioxide emission problems, which raise the question whether the industrial agglomeration promotes or inhibits energy efficiency and carbon dioxide emission. This paper explored the effects of the industrial agglomeration on carbon efficiency in China. Spatial econometric methods were implemented using panel data (2007-2016) of 285 cities above the prefecture level. The results revealed that industrial agglomerations have significant impacts on the urban carbon efficiency with significant spatial spillover effects. The agglomerations of the manufacturing and high-end productive service industries take positive effects on carbon efficiency while the low-end productive and living service industries take negative effects. As a comparison, we found that the agglomeration effects at the level of the megalopolis are greater than those at the national level, especially for the living services industry, in which the higher levels of agglomeration make the effects on carbon efficiency change from negative to positive. The divisions of labor for the central and common cities in the megalopolises are integrated into the industrial agglomeration. Furthermore, the fractionalorder grey forecasting model is used in this paper. By the virtue of its advantage in dealing with small sample data which lack statistical rules, this paper makes an out-of-sample prediction of carbon efficiency and industrial agglomeration degree of Chinese cities. By adding the predicted results to the spatial correlation test, new evidence on the spatial correlation of carbon efficiency and spatial division of labor between cities is obtained. Based on the empirical results of the present study, we have proposed some policy recommendations.
\end{abstract}

\section{Introduction}

Since its reform and opening up, China's rapid urbanization process has brought about a significant increase in energy consumption and $\mathrm{CO}_{2}$ emissions. During 1980-2014, China's average annual growth rate of $\mathrm{CO}_{2}$ emissions was as much as $9.2 \%$. The International Energy Agency (IEA) reported that China has, since 2007, far exceeded the $\mathrm{CO}_{2}$ emissions of the European Union and the United States [1]. At present, according to statistics from the World Bank, China's $\mathrm{CO}_{2}$ emissions had reached 10.29 billion tons, accounting for $28 \%$ of global $\mathrm{CO}_{2}$ emissions in 2014. In comparison, in 2014, the $\mathrm{CO}_{2}$ emissions of the European Union and the United States were only 3.24 and 5.25 billion tons, respectively [2]. There is no doubt that the Chinese government faces an increasing amount of international and domestic pressure while keeping economic development stable. The Chinese government has made a list of commitments for reducing carbon emissions and to curb global climate change. In 2014, the Chinese government announced, in the "Sino US joint statement on climate change," that it plans to reach the peak of $\mathrm{CO}_{2}$ emissions by 
2030. At the 2015 Paris Climate Conference, the Chinese government committed to $\mathrm{CO}_{2}$ emissions per unit of GDP being $60-65 \%$ lower in 2030 than the level in 2005. Accordingly, China has enhanced a series of restrictions on $\mathrm{CO}_{2}$ emissions. For instance, China has controlled the expansion of the production capacity of the manufacturing industry because this industry produces high levels of pollution, consumes a large amount of energy, and is responsible for high $\mathrm{CO}_{2}$ emissions. China has intentionally reduced its reliance on the manufacturing industry to achieve industrial upgrading. However, the implementation of restrictions on the manufacturing industry is bound to slow down economic growth.

In the process of economic development, cities are regarded as carriers of economic activities and also account for about $85 \%$ of China's $\mathrm{CO}_{2}$ emissions [3]. The rapid urbanization increases not only massive $\mathrm{CO}_{2}$ emissions but also the level of total factor productivity (TFP) with the accumulation of the population, economic factors, and activities in the cities [4]. An improvement of the TFP plays an essential role in promoting economic growth and transformation $[5,6]$, as well as improving efforts to reduce energy consumption and $\mathrm{CO}_{2}$ emissions $[7,8]$. Therefore, the economies of scale and technology spillover effects will inevitably affect the quantity and efficiency of $\mathrm{CO}_{2}$ emission. In this sense, the effective use of urban industrial agglomeration effects is conducive to not only reducing $\mathrm{CO}_{2}$ emissions but also promoting economic growth.

Many scholars studied how urbanization improves carbon efficiency from the perspective of agglomeration economies. Most scholars identified that the driving factors for improving carbon efficiency are the aggregation of the population, technological progress, and industrial structure. For example, $\mathrm{Li}$ et al. studied the efficiency of $\mathrm{CO}_{2}$ emissions of China's 31 manufacturing industries, from 2012 to 2016, and found that the high-tech industry ranked at the top of the list of industries with different levels of technology [9]. Wang et al. discovered that the energy structure, technological level, and rate of urbanization all have significant impacts on carbon efficiency [10]. Sun et al. evaluated the carbon efficiency and the global value chain (GVC) position index. They highlighted that, compared with the labor-intensive and resource-intensive manufacturing industries, the technology-intensive manufacturing industry in the GVC is most effective in improving carbon efficiency [11]. Zhang et al. indicated that enterprise size is a crucial factor for improving carbon efficiency [12]. Wang and Ma determined that the level of urbanization, the structure of energy consumption, and the level of industrialization are the main driving factors of $\mathrm{CO}_{2}$ emissions [13]. Wang et al. found that the gradual improvement of the level of technology is the main driving force for the improvement of the efficiency of $\mathrm{CO}_{2}$ emissions $[14,15]$. Wang et al. found that the production technology shows heterogeneities at the level of region [16] and sector [17].

In general, technological progress, economies of scale, and the aggregation of the population will significantly affect the carbon efficiency. However, these studies did not discuss the agglomeration of the segmented service industries. Thus, it is unknown that how the impact of the spatial agglomeration of economic activity on carbon efficiency is derived from the agglomeration of services. Besides, according to the China Megalopolises Development Report 2010, megalopolises cover $21.13 \%$ of the national land area, accounting for $48.99 \%$ of the total population, $51.41 \%$ of the urban population, and $46.7 \%$ of the urban members. In addition, they create $81.94 \%$ of the added value of the second industry and $83.5 \%$ of the added value of the third industry. The megalopolis is an advanced form of spatial organization with a concentration of economic actions resulting from highly developed industrialization and urbanization [18]. The spatial characteristics of a megalopolis contribute to providing transportation, communication, information, and other infrastructures, as well as market conditions, which further stimulate the agglomeration of industries natively. However, few scholars have studied the relationship between industrial agglomeration and carbon efficiency in megalopolises.

Compared to the extant research, the present study makes three major contributions: (1) the present study built a spatial Durbin model to study the effects of the heterogeneity of the industrial agglomeration on carbon efficiency at the national level and at the level of the megalopolis; (2) we explored the different impacts from various service industry agglomerations on urban carbon efficiency and identified specific impacts in megalopolises; (3) comparisons between the manufacturing and segmented service industries were made, and finally, we sought the optimal development path of cities for the dual goals of economic development and the reduction of $\mathrm{CO}_{2}$ emissions.

\section{Theoretical Frameworks and Research Hypotheses}

At present, most urban-related studies focused on the relationship between different types of industrial agglomeration and the labor productivity of a single city, but no consistent conclusions could be drawn. First, some studies showed that industrial agglomeration has caused serious environmental pollution along with the expansion of enterprise-scale and large-scale use of energy from fossil fuels. Virkanen found that industrial agglomeration in southern Finland caused heavy metal pollution of the local water resources and atmosphere [19]. Verhoef and Nijkamp found that industrial agglomeration harms the quality of the environment, leading to the aggravation of environmental pollution [20]. Frank et al. showed that industrial agglomeration worsens air quality in sampled cities in the European Union [21]. Duc et al. surveyed industrial companies on both sides of the Vietnamese river and found that industrial agglomeration caused river pollution [22]. In contrast to mentioned above, some scholars further discovered that industrial agglomeration is conducive to the progress and diffusion of environmental protection technology, promoting production and energy 
efficiencies, and reducing environmental pollution [23-27]. Han et al. analyzed the impact of Marshall's agglomeration, such as labor concentration effects, economies of scale of intermediate inputs, and space spillover effects, on industrial energy efficiency. They pointed out that the space availability of intermediate inputs and space technology spillover effects significantly increase industrial energy efficiency [28]. Furthermore, Han et al. constructed a spatial Durbin model to explore the effects of industrial specialization and diversified agglomerations of manufacturing on $\mathrm{CO}_{2}$ emissions. They provided an evidence that both of them can reduce $\mathrm{CO}_{2}$ emissions locally and in surrounding cities through the agglomeration of economic externalities [29]. Zhang et al. analyzed data from 18 cities in Henan Province and proposed that industrial agglomeration reduces $\mathrm{CO}_{2}$ emissions in the surrounding areas and that there is a negative impact on the intensity of $\mathrm{CO}_{2}$ emissions [30]. Shen et al. used a dynamic spatial panel model and demonstrated that the agglomeration of the productive service industries has a significant positive space spillover effect on energy efficiency in surrounding areas [31]. Jacobs et al. found that diversified agglomeration is available for the high-end productive service industry in central cities, such as large and international cities. They found that the industries of these cities have the characteristics of high added value within products, a large service radius, and a small transaction frequency, thus affecting the surrounding areas with significant spatial spillover effects of improvements in energy efficiency [32]. However, in the existing literature, there is an absence of research on the low-end productive services and living services. In addition, there are no comparative studies between the manufacturing and service industries, or with the inter-heterogeneity in the subdivided service industries, regarding the effects of industrial agglomeration on urban carbon efficiency. Therefore, we propose Hypothesis 1.

Hypothesis 1. The agglomeration effects of various industries show heterogeneity, and their impacts on urban carbon efficiency have diversity spatially.

The urban area provides transportation, communication, information, and other infrastructures as well as market conditions and stimulates the agglomeration of industries. The development of industrial agglomeration is part of the trend of urbanization, resulting in the industries being close to the source of innovation of the central city to obtain advanced technology. When the urbanization is in different stages, the internal industrial agglomeration pattern has different characteristics. The expansion of cities promotes the diffusion and re-agglomeration of industries. The second industry cluster is dominant in the developing stage of urbanization, while the third industry cluster is evident in the developed stage. The coordinated development of regional industrial agglomeration and urbanization promotes the overall development of the regional economy. Therefore, cities of different scales and grades are adjacent to each other or cities of the same scale and grade in space. This will form a megalopolis through strengthening the division of labor and cooperation between cities. Huang et al. argued that the development of a megalopolis is beneficial to the improvement of urban ecological efficiency and that the degree of improvement is affected by the city level [33]. Yue et al. found that the impact of an industrial structural adjustment on the energy intensity of cities in the Pearl River Delta is not apparent [34]. Chen et al. found that the transfer of high energy-consuming industries, which are led by capital-intensive industries, from the developed region to the developing region, can effectively reduce $\mathrm{CO}_{2}$ emissions in the developed regions [35]. Li et al. indicated that industrial transfer between any two cities within a megalopolis would bring about a decline in energy intensity [36]. Xiao et al. revealed that the performance of the total-factor $\mathrm{CO}_{2}$ emissions of the tertiary industry is better than that of the secondary industry. However, prospects for the low-carbon development of the tertiary industry, in the Yangtze River Delta, are not optimistic [37]. Therefore, we propose Hypothesis 2 .

Hypothesis 2. The diversified characteristics of the industrial agglomeration of a megalopolis in space result in its effects on carbon efficiency being different.

The structural optimization effect is the driving force for improving carbon efficiency in a megalopolis. First, the development of megalopolises improves the proportion of production service industries and promotes the diversification of production in central cities. Second, the development of megalopolises promotes their industrialization progress and the specialization of production in common cities. Henderson pointed out that there is an inverted $U$ shaped relationship between urban scale and industrial agglomeration. With the expansion of the urban scale, the competition for urban public resources, the rise of factor costs, the congestion of transportation, and other factors will accelerate the industrial diffusion. Simultaneously, some industries leapfrog to the same level or to a low gradient city, namely, Friedman's "centre-periphery" mode, which leads to the initial formation of megalopolises [38, 39]. In recent years, megalopolises have played an essential role in China's new urbanization process [40]. In the Yangtze River Delta, the development of the service industry in Shanghai far exceeds other industries, but the manufacturing industry still leads and plays a decisive role in Jiangsu and Zhejiang [41]. The Pearl River Delta has entered the post-industrialization period and has developed with the promotion of the agglomeration of the service industry and manufacturing diffusion [35]. In the Circum-Bohai Sea Economic Zone, the heavy industry accounts for too large a share of the overall economy, which restricts the division of labor between the cities [42]. Yu et al. found that there is a negative correlation between the size of a city and carbon emissions and further demonstrated that a megalopolis is more efficient with regard to carbon emissions [43]. Liu et al. deemed that the social, land, population, and economic urbanization are all related to urbanization and conducted an assessment of the multiple effects of these components of urbanization on $\mathrm{CO}_{2}$ emissions in the Pearl River Delta [44-46]. Zheng et al. predicted that the energy consumption of the Yangtze River 
Delta would continue to rise, and the main source of energy consumption will be manufacturing. They also suggested that the government should update its methods and concepts related to sustainable development and limit the development of energy-intensive industries [41]. Ouyang et al. found that GDP per capita, environmental regulation strength, factor input structure, foreign direct investment, local government spending, and the degree of openness have positive impacts on the industrial total-factor energy efficiency in the Pearl River Delta [47]. Li et al. argued that socioeconomic factors, such as the industrial structure, economic level, carbon intensity, and other spatial factors, play significant roles in decreasing carbon intensity in the Yangtze River Delta [48]. Therefore, the development of megalopolises improves the proportion of the tertiary industry in central cities and also promotes the progress of both industrialization and specialized production in common cities. The development of megalopolises decentralizes the diseconomy of agglomeration of central cities and promotes the flow of the elements of production to common cities. However, although the aforementioned studies have contributed to the theoretical discussion on the mechanism by which industrial agglomeration influences economic development of megalopolis, they still lack empirical support. On the basis of these studies, we propose the following.

Hypothesis 3. On the internal side of a megalopolis, the division of labor between central and common cities is coupled with industrial agglomeration for improving carbon efficiency.

\section{Data and Methodology}

Limited by the availability of data, the present study selected panel data (2007-2016) for 285 cities in China. The original data sources were the China City Statistical Yearbook, China Energy Statistics Yearbook, and Beijing Shu Huitong Environmental Technology Research Institute Data Service Network (http://www.3edata.com). To ensure the consistency and comparability of the statistical data, the present study used the relatively stable statistical caliber of the city.

3.1. Measurement of $\mathrm{CO}_{2}$ Emissions at Prefecture-Level Cities. Given the availability of data sources, we selected four forms of energy consumption, electricity, natural gas, liquefied petroleum gas, and transportation industries, to measure $\mathrm{CO}_{2}$ emissions [49].

To better reflect the actual situation in China, the reference coefficient of coal for various energy conversions and the average low calorific value were adopted from the Chinese National Standard GB/T2589-2008. The data of the unit calorific value of the carbon content and the oxidation rate used to calculate the $\mathrm{CO}_{2}$ emission coefficient were obtained from the "2006 IPCC National Greenhouse Gas Emission Inventory Guide." The formula used to calculate the $\mathrm{CO}_{2}$ emissions is as follows:

$$
C=\sum C_{i j}=\sum E_{i j} \times f_{i j}
$$

where $C$ denotes the $\mathrm{CO}_{2}$ emissions, $i$ is the $i$-th energy, $j$ is the $j$-th city (region), $C_{i j}$ denotes the $\mathrm{CO}_{2}$ emissions generated by the $i$-th energy consumption in city $j$, and $E_{i j}$ is the consumption of the $i$-th energy in city $j$, and $f_{i j}$ represents the $\mathrm{CO}_{2}$ emission coefficient of the $i$-th energy in city $j$.

The average low calorific value, carbon content per unit calorific value, carbon oxidation rates of the principal energies, and calculated $\mathrm{CO}_{2}$ emission factors are shown in Table 1.

Data on the electricity consumption of the whole society were collected from the China City Statistical Yearbook. Glaeser and Kahn argued that there is an independent $\mathrm{CO}_{2}$ emission coefficient in each regional power grid [50]. Accordingly, we divide China into six regions: North China, Northeast China, East China, Central China, Northwest China, and South China. The $\mathrm{CO}_{2}$ emission coefficient for electricity was measured according to the baseline emission coefficient in the regional grid, which was issued by the China Certified Emission Reduction Exchange Information Platform.

The data on the supplies of natural gas and liquefied petroleum gas in a region were obtained from the data service network of the Beijing Shu Huitong Environmental Technology Research Institute. The $\mathrm{CO}_{2}$ emission coefficient of natural gas is $0.2666 \mathrm{~kg} / \mathrm{m}^{3}$, and the $\mathrm{CO}_{2}$ emission coefficient of liquefied petroleum gas is $3.1013 \mathrm{~kg} / \mathrm{m}^{3}$.

Due to differences between the regions of China and incomplete statistical data, it was difficult to obtain data such as mileage travelled by vehicle, the fuel used per mile for different types of motor vehicles, etc. According to public data, it is less accurate to use the "bottom-up" method to calculate $\mathrm{CO}_{2}$ emissions from transportation. In the present study, we use a "top-down" algorithm to calculate the $\mathrm{CO}_{2}$ emissions by transportation in various cities in China. The $\mathrm{CO}_{2}$ emissions from transportation mainly come from direct emissions from the combustion of fossil fuels. In contrast, the indirect emissions of $\mathrm{CO}_{2}$ from electricity and heat consumption are less. Therefore, in the present study, the calculations of $\mathrm{CO}_{2}$ emissions by transportation included only the direct emissions from the consumption of fossil fuels.

At the provincial level, the Regional Energy Balance Sheet contains the energy consumed by transportation, warehousing, and postal industries. The present study excluded the energy consumption of the warehousing and postal industries. This was achieved by using the income ratios of transportation, warehousing, and postal industries in the "China Economic Census Yearbook" to estimate energy consumption and calculate $\mathrm{CO}_{2}$ emissions for the transportation industry only. Then, referring to Li et al. [51], we obtained the values of the passenger and freight turnovers from the China Economic Network Statistics Database and the energy intensity data in the Transportation Energy Data Book (TEDB). These were used to calculate the ratio of $\mathrm{CO}_{2}$ emissions between passenger and freight transport. According to this ratio, we divided the $\mathrm{CO}_{2}$ emissions by the transport activities for passenger and freight at the provincial level. At the city level, we calculated the proportion of the volume of the passenger transport of each city and that of 
TABLE 1: The $\mathrm{CO}_{2}$ emission coefficients of the principal energy sources.

\begin{tabular}{|c|c|c|c|c|}
\hline Energy & Average low calorific value & Carbon content per unit calorific value & Carbon oxidation rates & $\begin{array}{l}\mathrm{CO}_{2} \text { emission } \\
\text { factors }\end{array}$ \\
\hline Raw coal & $20908 \mathrm{~kJ} / \mathrm{kg}$ & 26.37 & 0.94 & $1.9002 \mathrm{~kg} / \mathrm{kg}$ \\
\hline Washed coal & $26344 \mathrm{~kJ} / \mathrm{kg}$ & 25.41 & 0.94 & $2.3072 \mathrm{~kg} / \mathrm{kg}$ \\
\hline Other coal washing & $8363 \mathrm{~kJ} / \mathrm{kg}$ & 25.41 & 0.94 & $0.7324 \mathrm{~kg} / \mathrm{kg}$ \\
\hline Briquette & $1589 \mathrm{~kJ} / \mathrm{kg}$ & 33.56 & 0.9 & $0.1762 \mathrm{~kg} / \mathrm{kg}$ \\
\hline Coke & $28435 \mathrm{~kJ} / \mathrm{kg}$ & 29.42 & 0.93 & $2.8604 \mathrm{~kg} / \mathrm{kg}$ \\
\hline Coke oven gas & $173535 \mathrm{~kJ} / \mathrm{m}^{3}$ & 12.1 & 0.98 & $7.5452 \mathrm{~kg} / \mathrm{m}^{3}$ \\
\hline Blast furnace gas & $3763 \mathrm{~kJ} / \mathrm{m}^{3}$ & 70.8 & 0.99 & $0.9671 \mathrm{~kg} / \mathrm{m}^{3}$ \\
\hline Converter gas & $5227 \mathrm{~kJ} / \mathrm{m}^{3}$ & 49.6 & 0.99 & $0.9411 \mathrm{~kg} / \mathrm{m}^{3}$ \\
\hline Crude & $41816 \mathrm{~kJ} / \mathrm{kg}$ & 20.08 & 0.98 & $3.0202 \mathrm{~kg} / \mathrm{kg}$ \\
\hline Gasoline & $41070 \mathrm{~kJ} / \mathrm{kg}$ & 18.9 & 0.98 & $2.9251 \mathrm{~kg} / \mathrm{kg}$ \\
\hline Kerosene & $43070 \mathrm{~kJ} / \mathrm{kg}$ & 19.6 & 0.98 & $3.0334 \mathrm{~kg} / \mathrm{kg}$ \\
\hline Diesel & $42652 \mathrm{~kJ} / \mathrm{kg}$ & 20.2 & 0.98 & $3.0959 \mathrm{~kg} / \mathrm{kg}$ \\
\hline Fuel oil & $41816 \mathrm{~kJ} / \mathrm{kg}$ & 20.1 & 0.98 & $3.1705 \mathrm{~kg} / \mathrm{kg}$ \\
\hline Liquefied petroleum gas & $50179 \mathrm{~kJ} / \mathrm{m}^{3}$ & 17.2 & 0.98 & $3.1013 \mathrm{~kg} / \mathrm{m}^{3}$ \\
\hline Refinery dry gas & $46055 \mathrm{~kJ} / \mathrm{m}^{3}$ & 18.2 & 0.98 & $3.0119 \mathrm{~kg} / \mathrm{m}^{3}$ \\
\hline Other petroleum products & $40200 \mathrm{~kJ} / \mathrm{kg}$ & 20 & 0.98 & $2.889 \mathrm{~kg} / \mathrm{kg}$ \\
\hline Natural gas & $4800 \mathrm{~kJ} / \mathrm{m}^{3}$ & 15.32 & 0.99 & $0.2666 \mathrm{~kg} / \mathrm{m}^{3}$ \\
\hline Liquified natural gas & $44200 \mathrm{~kJ} / \mathrm{m}^{3}$ & 17.2 & 0.98 & $2.7318 \mathrm{~kg} / \mathrm{m}^{3}$ \\
\hline
\end{tabular}

the freight transport of each city in a province. We then divided the provincial $\mathrm{CO}_{2}$ emissions into the city level in terms of each calculated proportion. Finally, we aggregated the $\mathrm{CO}_{2}$ emissions data of the passenger and freight transports as the total emissions for the transportation industry of the prefecture-level cities.

According to Figure 1, from 2007 to 2016, the total $\mathrm{CO}_{2}$ emissions of China's prefecture-level cities increased from 2022.77 to 3499.70 million tons, with an average annual growth rate of $6.31 \%$. The $\mathrm{CO}_{2}$ emissions of cities in megalopolises increased from 1065.89 to 1741.97 million tons, with an average annual growth rate of $5.63 \%$. The $\mathrm{CO}_{2}$ emissions of other cities increased from 956.89 to 1757.72 million tons, and the average growth rate was $7.04 \%$. There has been an annual decrease in the proportion of $\mathrm{CO}_{2}$ emissions in megalopolises. During 2007-2016, the 70 cities in three megalopolises contributed an average of $50.37 \%$ of the total $\mathrm{CO}_{2}$ emissions among 285 above prefecture-level cities across the country. This means that the megalopolises are still the main sources of China's $\mathrm{CO}_{2}$ emissions.

3.2. Spatial Distribution of $\mathrm{CO}_{2}$ Emissions. According to Tobler's first law, everything is related to other things, and similar things are more closely related to each other. This means that spatial data can interact with each other due to geographical location. We explored the spatial distribution of $\mathrm{CO}_{2}$ emissions in 2007, 2011, and 2016 in above prefecture-level cities. As shown in Figure 2, $\mathrm{CO}_{2}$ emissions show distinct spatial agglomeration characteristics. $\mathrm{CO}_{2}$ emissions decreased gradually along the east, central, and west areas. The Pearl River Delta, Yangtze River Delta, Beijing-Tianjin-Hebei Economic Zone, and ChengduChongqing Economic Zone, which are the largest and most developed areas in China, showed higher levels of emissions. Shandong and Liaoning Provinces showed significantly high concentrations of emissions, which combined with the Tianjin-Hebei Economic Zone form the Circum-Bohai Sea Economic Zone.

3.3. Measurement of the Agglomeration of the Service and Manufacturing. As for the measurement of industrial agglomeration, a series of measurement methods are available, such as market concentration, location entropy, Herfindahl index, spatial Gini coefficient, geographic concentration index, and MS index. Each of them has its own focus. The location entropy measures industrial agglomeration through industrial specialization, which is conducive to indicating the advantageous industries in the region. The Herfindahl index reflects the concentration of enterprises in the industry, and the spatial Gini coefficient reflects the regional agglomeration of the industry. The geographic concentration index comprehensively evaluates the degree and structure of industrial agglomeration. Accordingly, to find the dominant industries and leading industries in different cities, the present research concentrated on evaluating the impacts of different industrial agglomerations, in different regions, on the local and surrounding carbon efficiencies. The number of employees for each industry was obtained from public data. Therefore, we used the location entropy to measure the level of urban industrial agglomeration. The formula for calculating the industrial agglomeration level is

$$
L Q_{i j}=\frac{e_{i j} / e_{j}}{E_{i} / E},
$$

where $e_{i j}$ indicates the number of employees in industry $i$ in city $j, e_{j}$ indicates the total number of employees in city $j, E_{i}$ indicates the total number of employees in industry $i$ in the country, and $E$ indicates the total number of employees in the country. The larger the value of $L Q_{i j}$, the more obvious 


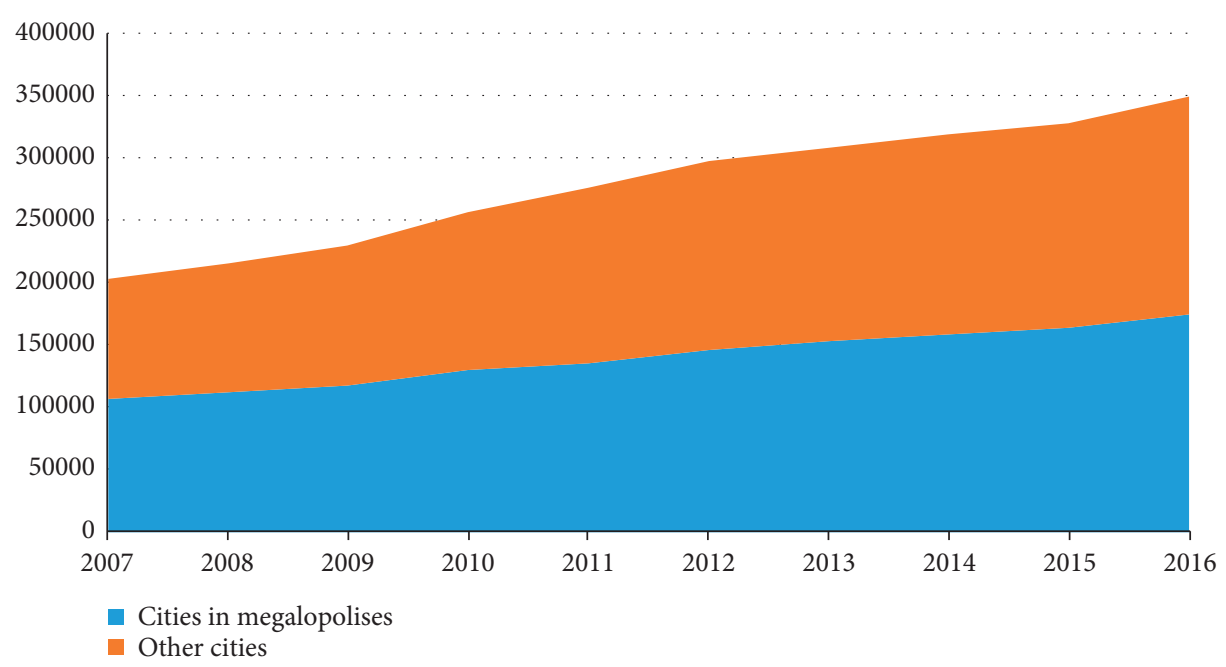

Figure 1: The $\mathrm{CO}_{2}$ emissions in megalopolises and other cities from 2007 to 2016 (unit: 10,000 ton).

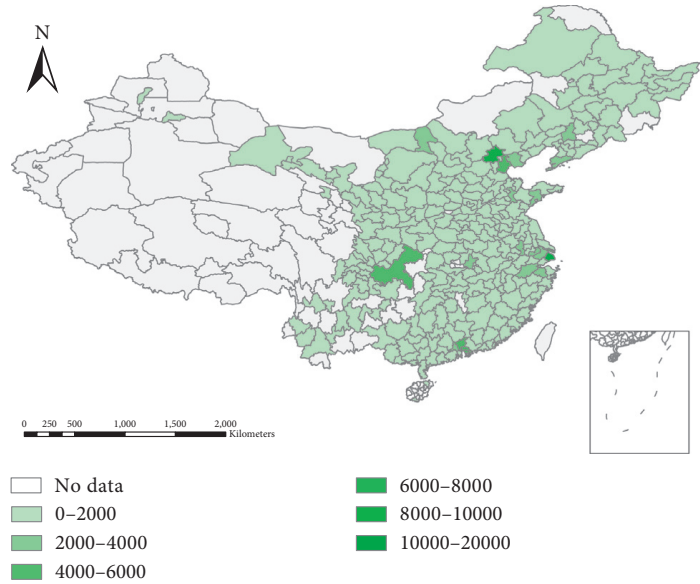

(a)

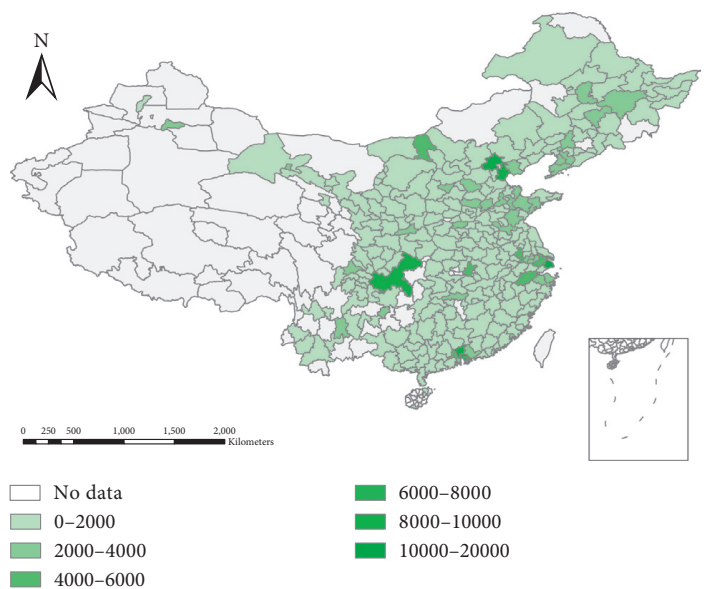

(c)
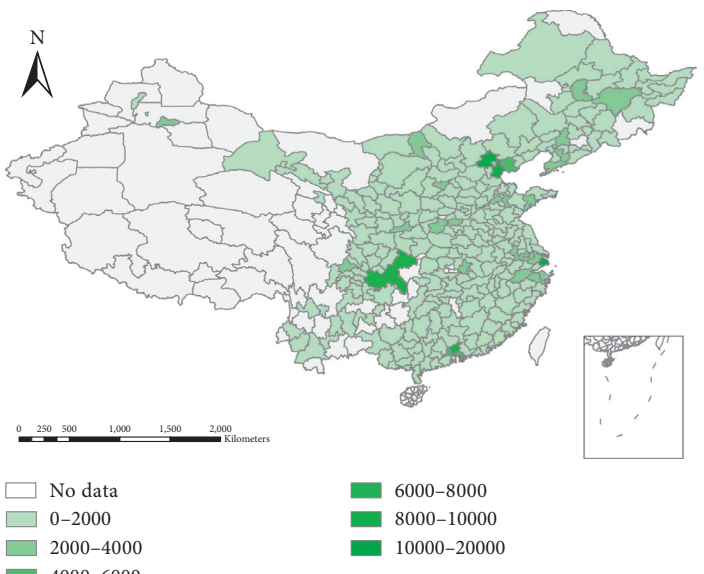

(b)

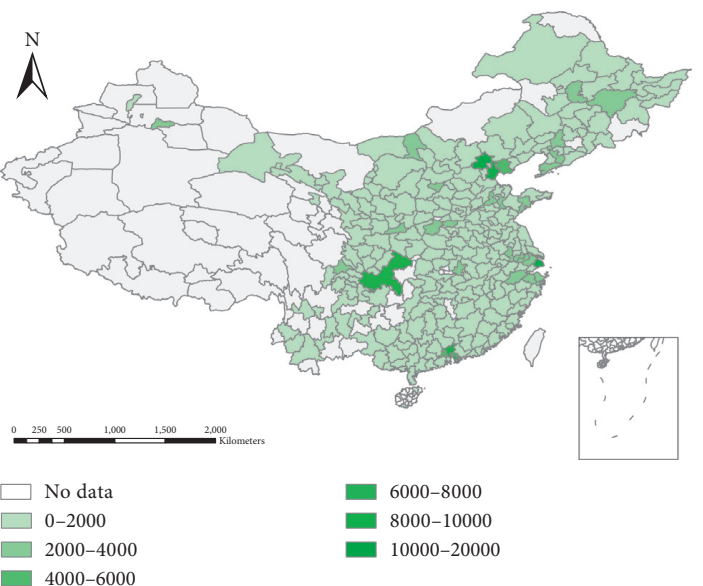

(d)

Figure 2: The spatial distribution of $\mathrm{CO}_{2}$ emissions at the city level in China. (a) $\mathrm{CO}_{2}$ emissions in 2007. (b) $\mathrm{CO}_{2}$ emissions in 2011. (c) $\mathrm{CO}_{2}$ emissions in 2016. (d) Average of $\mathrm{CO}_{2}$ emissions from 2007 to 2016.

the agglomeration advantage. When $L Q_{i j}>1$, it indicates that the development intensity of the industry in the region is higher than the national average for similar industries; when $L Q_{i j}>1.5$, it indicates that the development intensity of the industry in the region has a significant comparative advantage. 
In the manufacturing sector, due to the lack of complete classification statistics for the above prefecture-level city, the preset study analyzed it as a whole and could not discuss the segmented manufacturing industries any further. In 2011, China established classification standards for the 15 subindustries of the service sector. Complete employment statistics were available at the city level, and the preset study categorized them accordingly. In the classification of the service industries, referring to $\mathrm{Li}$ and $\mathrm{Li} \mathrm{[52]} \mathrm{and} \mathrm{Lu}$ [53], we divided the service sector into three categories: (1) the productive service industries whose service targets are the manufacturers of industrial goods; (2) the living service industries who serve to the final consumer; and (3) the public service industries whose providers are governments. The public administrations determine the size of the public service industry, and it was not discussed in the present study. In terms of the intensity of knowledge accumulation in the productive service industry, there exist high-end productive service industries with strong knowledge accumulation and low-end productive service industries with low knowledge accumulation [54]. Accordingly, this paper focused on the specific industries within manufacturing, productive services (high-end and low-end), and living services (see Table 2).

Based on the original data of employees in 285 above prefecture-level cities in China, the location entropy calculation formula was used to measure the average annual value of agglomeration level of each industry in various cities (Figure 3). Figure 4 shows the average location entropy in the different areas.

As shown in Figure 3, manufacturing showed a significant aggregation in space, especially in the eastern coastal areas. However, there were no apparent spatial agglomerations in the distributions of the service industries. In Figure 4, the average degree of the manufacturing agglomeration of each megalopolis was higher than that at the national level. The levels of manufacturing agglomeration decreased in the order of the Pearl River Delta, Yangtze River Delta, and Circum-Bohai Sea Economic Zone, respectively. The average concentrations of all kinds of service industries in the Circum-Bohai Sea Economic Zone were higher than those in the Pearl River Delta and the Yangtze River Delta. The concentration of the productive service industry in the Pearl River Delta was the lowest of the three megalopolises.

3.4. Fractional-Order Grey Forecasting Model. At present, there are two popular methods to make forecasting: (1) the white box models, commonly used as the differential equations, and (2) the black box models, such as the machine learning models. The grey models take the merits of above models. Especially, the grey models are good at modeling time series forecasting in small sample [55]. The grey model is between the black model and the white model. It contains both unknown information and known information. At the same time, the factors in the system have uncertain relations, and the biggest characteristic is that the accumulation process can reflect the regularity of the data. This model has been applied well in many fields since its establishment [56]. The old grey models all are integer derivative models, which belong to ideal memory models and are not suitable for describing some irregular phenomena. In fact, the grey model is usually fractional. For example, the weather is the derivative of fractional order of climate, so it is the bridge between cause and effect in the complex system. Moreover, when the objects with fractional characteristics are described by fractional order, the essential characteristics and behaviors of the objects can be better revealed [57]. Therefore, this method is capable to describe dynamic behavior of the processes and systems with high accuracy and concise models. The economic phenomena are the activities of multiagent social system, so fractional-order grey forecasting is capable for addressing our topic.

Referring to $\mathrm{Wu}$ [55], this paper used the fractionalorder grey forecasting model to forecast the carbon efficiency and industrial agglomeration degree of each prefecture-level city from 2017 to 2021 . The modeling steps are as follows.

Step 1. The cumulative sequence of order $(p / q)$ was calculated:

$$
X^{(p / q)}=\left(x^{(p / q)}(1), x^{(p / q)}(2), \ldots, x^{(p / q)}(n)\right) .
$$

Step 2. A non-negative sequence, $X^{(0)}=\left(x^{0}(1), x^{0}(2)\right.$, $\left.\ldots, x^{0}(n)\right)$, should be an accumulation operator of order $p / q(0<(p / q)<1) . \quad$ Stipulate $\quad C_{(p / q)-1}^{0}=1, C_{k}^{k+1}=0$, $k=0,1, \ldots, n-1, C_{k-i+(p / q)-1}^{k-i}=(((k-i+(p / q)-1)(k-i+$ $(p / q)-2), \ldots,((p / q)+1)(p / q)) /(k-i) !)$, and it is called a cumulative sequence of order $(p / q)(0<(p / q)<1)$.

Step 3. Substituting $x^{p / q}(k)(k=1,2, \ldots, n)$ into Step 2 , the least square method is used to estimate parameter $\left[\begin{array}{l}\hat{\beta}_{2} \\ \widehat{\beta}_{1}\end{array}\right]$.

Step 4. Using $x^{(p / q)}(k)=\left(x^{0}(1)-\left(\widehat{\beta}_{2} /\left(1-\widehat{\beta}_{1}\right)\right)\right) \widehat{\beta}_{1}^{(k-1)}+$ $\left(\widehat{\beta}_{2} /\left(1-\widehat{\beta}_{1}\right)\right)$ to predict $\widehat{x}^{(p / q)}(1), \widehat{x}^{(p / q)}(2), \ldots$, .

Step 5. Decrease $X^{(p / q)}=\left(\hat{x}^{(p / q)}(1), \hat{x}^{(p / q)}(2), \ldots, \hat{x}^{(p / q)}\right.$ $(n), \ldots$,$) by order (p / q)$. That is,

$$
\alpha^{(p / q)} X^{(0)}=\left(\alpha^{(1)} \widehat{x}^{1-(p / q)}(1), \alpha^{(1)} \widehat{x}^{1-(p / q)}(2), \ldots, \alpha^{(1)} \widehat{x}^{1-(p / q)}(n), \alpha^{(1)} \widehat{x}^{1-(p / q)}(n+1), \ldots,\right)
$$


TABLE 2: A classification of the service industries.

\begin{tabular}{lc}
\hline Name & Industry category \\
\hline $\begin{array}{l}\text { High-end productive } \\
\text { services }\end{array}$ & $\begin{array}{c}\text { Information transmission, computer services, and software; finance; scientific research, technical services, and } \\
\text { Low-end productive } \\
\text { services }\end{array}$ \\
$\begin{array}{l}\text { geological prospecting } \\
\text { Living services }\end{array}$ & $\begin{array}{c}\text { Transportation, warehousing, and postal services; leasing and business services } \\
\text { Wholesale and retail trade; accommodation and catering; resident services and other services; culture, sports, } \\
\text { and entertainment; real estate }\end{array}$
\end{tabular}

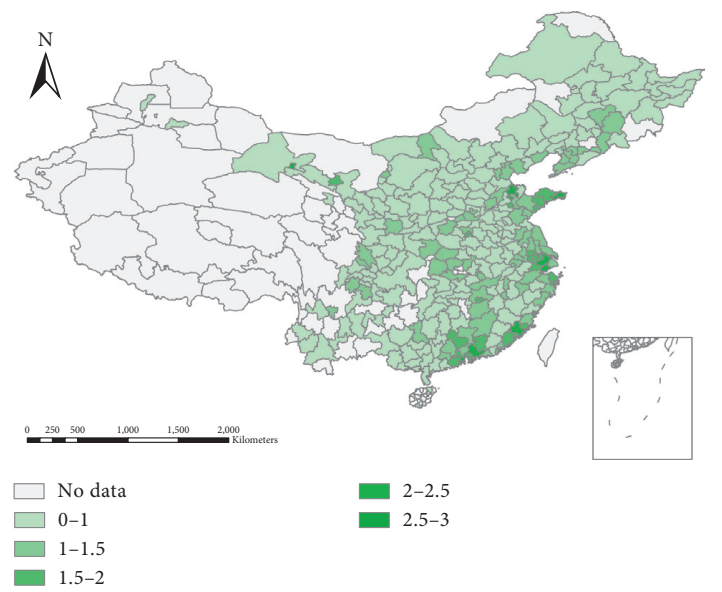

(a)

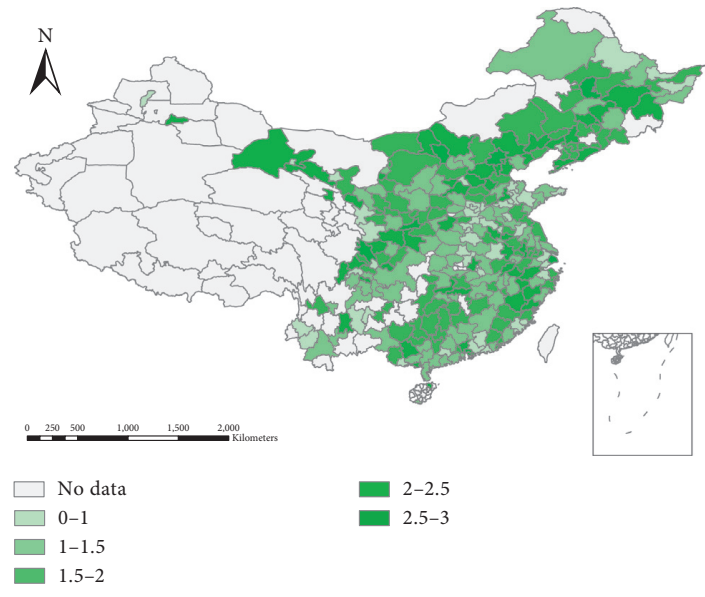

(c)
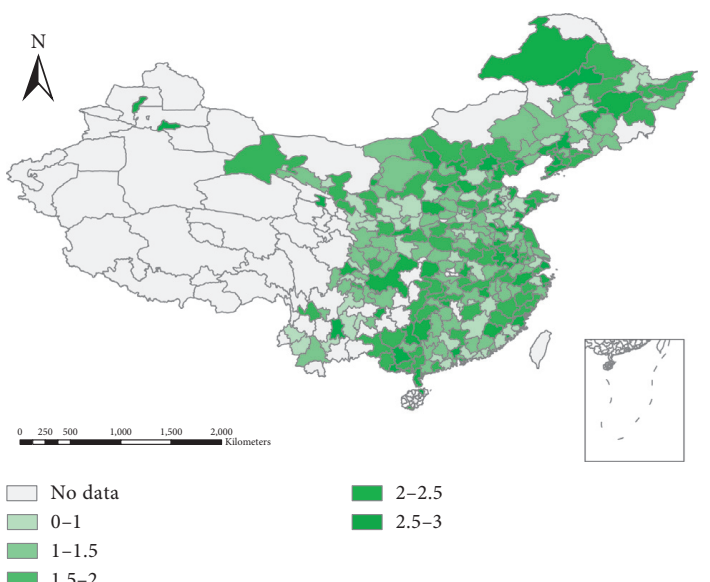

(b)

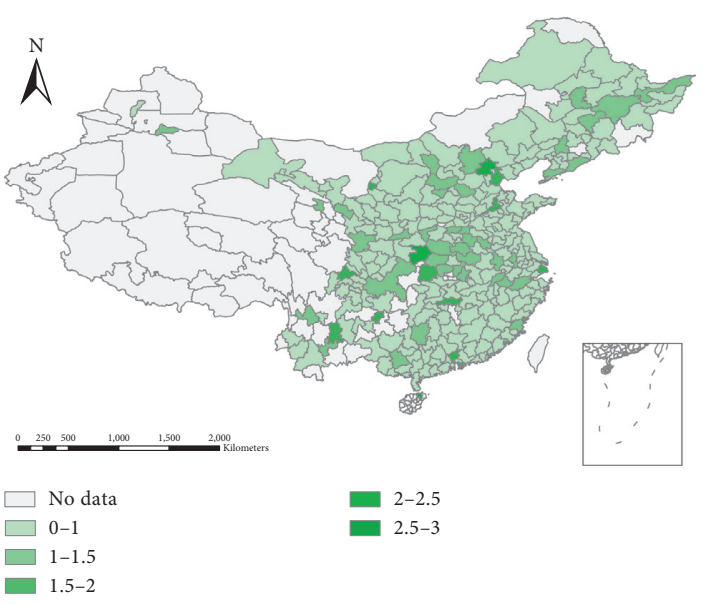

(d)

Figure 3: The spatial distribution of the average annual value (2007-2016) of the location entropy of each industry at city level. (a) Manufacturing industry. (b) Low-end productive service industry. (c) High-end productive service industry. (d) Living service industry.

\section{Econometric Models and Main Results}

4.1. Basic Model. Referring to Griliches [58], we assumed that the Cobb-Douglas function can manifest the production function of city $i$ at period $t$ :

$$
Y_{i t}=A\left(L_{i t}^{\alpha}\right)\left(K_{i t}^{\phi}\right)\left(E_{i t}^{\varphi}\right) e^{\varepsilon_{i t}}, \quad \alpha+\phi+\varphi=1,
$$

where $Y_{i t}$ is the desirable output, $L_{i t}, K_{i t}$, and $E_{i t}$ are the labor, capital, and energy consumption for urban production, respectively, $A$ denotes the total factor productivity, which is related to economies of economy, technology change, technology spillover, and institutional arrangements, $\alpha, \phi$, and $\varphi$ are the production elasticities, and $\varepsilon$ is the error term. Divide both sides of equation (5) by $\mathrm{C}\left(\mathrm{CO}_{2}\right.$ emission):

$$
\mathrm{YC}_{i t}=A\left(\mathrm{LC}_{i t}^{\alpha}\right)\left(\mathrm{KC}_{i t}^{\phi}\right)\left(\mathrm{EC}_{i t}^{\varphi}\right) e^{\varepsilon_{i t}} \text {, }
$$

where $\mathrm{YC}_{i t}=\left(Y_{i t} / C_{i t}\right)$ is the desirable output per unit of $\mathrm{CO}_{2}$ emissions, denoting the carbon efficiency. $\mathrm{LC}_{i t}=\left(L_{i t} / C_{i t}\right), \mathrm{KC}_{i t}=\left(K_{i t} / C_{i t}\right)$, and $\mathrm{EC}_{i t}=\left(E_{i t} / C_{i t}\right)$ are input factor-carbon ratios including labor, capital, and energy consumption, describing the efficiencies of input 


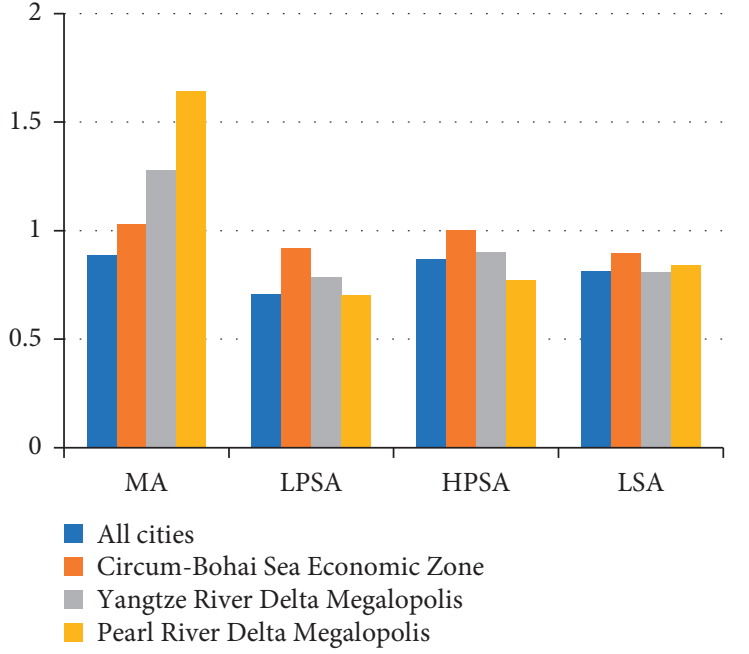

Figure 4: Averages of the location entropy in different areas (2007-2016).

factors. Therefore, the efficiencies of input factors are the decompositions of carbon efficiency. Take the logarithm form of equation (6) as follows:

$$
\ln \mathrm{YC}_{i t}=a+\alpha \ln \mathrm{LC}_{i t}+\phi \ln \mathrm{KC}_{i t}+\varphi \ln \mathrm{EC}_{i t}+\varepsilon_{i t},
$$

where $a=\ln A$. Also, we take government intervention (GOV) [59] and foreign direct investment (FDI) [60] as control variables in equation (7). The controlled model is

$$
\begin{aligned}
\ln \mathrm{YC}_{i t}= & a+\alpha \ln \mathrm{LC}_{i t}+\phi \ln \mathrm{KC}_{i t}+\varphi \ln \mathrm{EC}_{i t} \\
& +\lambda_{1} \ln \mathrm{GOV}_{i t}+\lambda_{2} \ln \mathrm{FDI}_{i t}+\varepsilon_{i t},
\end{aligned}
$$

where $\lambda_{1}$ and $\lambda_{2}$ are the elasticities of the control variables. Transform equation (8) into a matrix form:

$$
\mathbf{Y C}=\mathbf{A}+\alpha(\mathbf{L C})+\phi(\mathbf{K C})+\varphi(\mathbf{E C})+\lambda_{1} \mathbf{G O V}+\lambda_{2} \mathbf{F} \mathbf{D I}+\boldsymbol{\varepsilon} .
$$

In equation (9), A, LC, KC, EC, GOV, and F DI are the $N \times 1$ vectors of the logarithms of independent variables and $\varepsilon$ is the $N \times 1$ vector of error terms.

Moreover, the improvement of total factor productivity brought about by technological progress is another important way to improve carbon efficiency, other than improving the efficiency of input factors. The technology spillover and economies of scale, based on the theory of agglomeration economies, are two main driving forces promoting the total factor productivity $[61,62]$, which also will further strengthen carbon efficiency. Moreover, the effects of agglomeration not only affect the carbon efficiency in the local area but also affect surrounding cities [61, 63]. Therefore, we composed total factor productivity with the industrial agglomerations of native and surrounding cities. Accordingly, $A_{i t}$ can be set as

$$
\begin{aligned}
A_{i t}= & \theta_{0}\left(\mathrm{MA}_{i t}^{\theta_{1}}\right)\left(\operatorname{LPSA}_{i t}^{\theta_{2}}\right)\left(\operatorname{HPSA}_{i t}^{\theta_{3}}\right)\left(\operatorname{LSA}_{i t}^{\theta_{4}}\right), \\
& \prod_{j \neq i}^{N}\left(\mathrm{MA}_{j t}^{\vartheta_{1} w_{i j}}\right)\left(\operatorname{LPSA}_{j t}^{\vartheta_{2} w_{i j}}\right)\left(\operatorname{HPSA}_{j t}^{\vartheta_{3} w_{i j}}\right)\left(\operatorname{LSA}_{j t}^{\vartheta_{4} w_{i j}}\right) A_{j t}^{\delta w_{i j}},
\end{aligned}
$$

where $\theta_{0}$ is the exogenous variable noting an advanced technology for all cities national-wide; $\mathrm{MA}_{i t}$, LPSA $A_{i t}$, $\mathrm{HPSA}_{i t}$, and LSA ${ }_{i t}$ are manufacturing, low-end productive service, high-end productive service, and living service agglomerations for city $i$ at time $t$, respectively; $\theta_{1}, \theta_{2}, \theta_{3}$, and $\theta_{4}$ indicate the elasticities of the four kinds of industrial agglomeration; and $\mathrm{MA}_{j t}^{\vartheta_{1} w_{i j}}, \operatorname{LPSA}_{j t}^{\vartheta_{2} w_{i j}}$, $\mathrm{HPSA}_{j t}^{\vartheta_{3} w_{i j}}, \operatorname{LSA}_{j t}^{\vartheta_{4} w_{i j}}$, and $A_{j t}^{\delta w_{i j}}$ are geometrically weighted values of the agglomerations of manufacturing, low-end productive service, high-end productive service, living service, and the total factor productivity of neighboring cities. The degree of effects of industrial agglomeration among cities is described by identical $\vartheta_{1}, \vartheta_{2}, \vartheta_{3}, \vartheta_{4}$, and $\delta$, respectively. However, the net effects of these effects are dominated by the connectivity between each city, which can be described with the exogenous friction terms $w_{i j}$, where $j=1, \ldots, N$ and $j \neq i$. The closer the connectivity exists, the higher the value $w_{i j}$ takes. We took the logarithm of equation (10) and transformed it into a matrix form:

$$
\begin{aligned}
\mathbf{A}= & \boldsymbol{\theta}_{0}+\theta_{1} \mathbf{M A}+\theta_{2} \mathbf{L P S A}+\theta_{3} \text { HPSA }+\theta_{4} \mathbf{L S A} \\
& +\vartheta_{1} \text { WMA }+\vartheta_{2} \text { WLPSA }+\vartheta_{3} \text { WHPSA }+\vartheta_{4} \text { WLSA }+\delta \text { WA },
\end{aligned}
$$

where MA, LPSA, HPSA, and LSA are the $N \times 1$ vectors of the logarithms of industrial agglomeration and $\mathbf{W}$ is the $N \times$ $N$ matrix of the friction term $w_{i j}$. If $\vartheta_{1} \neq 0, \vartheta_{2} \neq 0, \vartheta_{3} \neq 0$, $\vartheta_{4} \neq 0$, and $\delta \neq 0$ and if $\left(1 / \vartheta_{1}\right),\left(1 / \vartheta_{2}\right),\left(1 / \vartheta_{3}\right),\left(1 / \vartheta_{4}\right)$, and $(1 / \delta)$ are not eigenvalues of $\mathbf{W}$, equation (11) can be transformed to

$$
\begin{aligned}
A= & (\mathbf{I}-\delta \mathbf{W})^{-1} \boldsymbol{\theta}_{0}+\theta_{1}(\mathbf{I}-\delta \mathbf{W})^{-1} \mathbf{M A}+\theta_{2}(\mathbf{I}-\delta \mathbf{W})^{-1} \mathbf{L P S A} \\
& +\theta_{3}(\mathbf{I}-\delta \mathbf{W})^{-1} \mathbf{H P S A}+\theta_{4}(\mathbf{I}-\delta \mathbf{W})^{-1} \mathbf{L S A}+\vartheta_{1}(\mathbf{I}-\delta \mathbf{W})^{-1} \mathbf{W M A} \\
& +\vartheta_{2}(\mathbf{I}-\delta \mathbf{W})^{-1} \mathbf{W L P S A}+\vartheta_{3}(\mathbf{I}-\delta \mathbf{W})^{-1} \mathbf{W H P S A}+\vartheta_{4}(I-\delta \mathbf{W})^{-1} \mathbf{W L S A} .
\end{aligned}
$$


Substitute equation (12) into equation (9) and multiply equation (9) by $(\mathbf{I}-\delta \mathbf{W})$ on both sides:

$$
\begin{aligned}
\mathbf{Y C}= & \boldsymbol{\theta}_{0}+\delta \mathbf{W Y C}+\theta_{1} \mathbf{M A}+\theta_{2} \mathbf{L P S A}+\theta_{3} \mathbf{H P S A}+\theta_{4} \mathbf{L S A}+\alpha \mathbf{L C}+\varphi \mathbf{K C} \\
& +\phi \mathbf{E C}+\lambda_{1} \mathbf{G O V}+\lambda_{2} \mathbf{F} \mathbf{D I}+\vartheta_{1} \mathbf{W M A}+\vartheta_{2} \mathbf{W L P S A}+\vartheta_{3} \mathbf{W H P S A} \\
& +\vartheta_{4} \mathbf{W L S A}+\vartheta_{5} \mathbf{W L C}+\vartheta_{6} \mathbf{W K C}+\vartheta_{7} \mathbf{W E C}+\vartheta_{8} \mathbf{W G O V}+\vartheta_{9} \mathbf{W F} \mathbf{D I}+\zeta
\end{aligned}
$$

where $\vartheta_{5}=-\alpha \delta, \vartheta_{6}=-\phi \delta, \vartheta_{7}=-\varphi \delta, \vartheta_{8}=-\lambda_{1} \delta, \vartheta_{9}=-\lambda_{2} \delta$, and $\xi=\varepsilon-\delta W \varepsilon$. Describe equation (13) with the subscript $i$ and obtain the carbon efficiency of city $i$ :

$$
\begin{aligned}
\ln \mathrm{YC}_{i t}= & \ln \theta_{0}+\delta \sum_{j \neq i}^{N} w_{i j} \mathrm{YC}_{i t}+\theta_{1} \ln \mathrm{MA}_{i t}+\theta_{2} \ln \mathrm{LPSA}_{i t}+\theta_{3} \ln \mathrm{HPSA}_{i t} \\
& +\theta_{4} \ln \mathrm{LSA}_{i t}+\alpha \ln \mathrm{LC}+\varphi \ln \mathrm{KC}+\phi \ln \mathrm{EC}+\lambda_{1} \ln \mathrm{GOV}+\lambda_{2} \ln \mathrm{FDI} \\
& +\vartheta_{1} \sum_{j \neq i}^{N} w_{i j} \ln \mathrm{MA}_{i t}+\vartheta_{2} \sum_{j \neq i}^{N} w_{i j} \ln \mathrm{LPSA}_{i t}+\vartheta_{3} \sum_{j \neq i}^{N} w_{i j} \ln \mathrm{HPSA}_{i t} \\
& +\vartheta_{4} \sum_{j \neq i}^{N} w_{i j} \ln \mathrm{LSA}_{i t}+\vartheta_{5} \sum_{j \neq i}^{N} w_{i j} \ln L C_{i t}+\vartheta_{6} \sum_{j \neq i}^{N} w_{i j} \ln \mathrm{KC}_{i t} \\
& +\vartheta_{7} \sum_{j \neq i}^{N} w_{i j} \ln \mathrm{EC}_{i t}+\vartheta_{8} \sum_{j \neq i}^{N} w_{i j} \ln \mathrm{GOV}_{i t}+\vartheta_{9} \sum_{j \neq i}^{N} w_{i j} \ln \mathrm{FDI}_{i t}+\zeta_{i t} .
\end{aligned}
$$

Equation (14), which includes both local effects and spatial effects, is called a spatial Durbin model. The descriptive statistics for the above variables are shown in Table 3. The original data sources were the China City Statistical Yearbook, China Energy Statistics Yearbook, and Beijing Shu Huitong Environmental Technology Research Institute Data Service Network (http://www.3edata.com).

\subsection{Spatial Weighted Matrix and Spatial Correlation Analysis.} Based on the availability of data sources, we constructed and standardized the weighted spatial matrix with a geographical distance matrix, where the sum of elements of each row is equal to one:

$$
W_{i j}=\frac{1}{d_{i j}^{2}}, \quad i \neq j,
$$

where $d_{i j}$ is the distance between each pair of cities based on latitudinal and longitudinal data, where $i \neq j$. The geographical attenuation parameter takes the value of 2. On the basis of $W_{i j}$, the present study used Moran's I index to measure the autocorrelation in the geographical distribution of the explained variables and the core explanatory variables:

$$
I=\frac{n}{\sum_{i=1}^{n} \sum_{j=1}^{n} W_{i j}} \times \frac{\sum_{i=1}^{n} \sum_{j=1}^{n} W_{i j}\left(X_{i}-\bar{X}\right)\left(X_{j}-\bar{X}\right)}{\sum_{i=1}^{n}\left(X_{i}-\bar{X}\right)^{2}},
$$

where $X_{i}$ is the value of the variable for region $i$. Moran's I index takes a value within $[-1,1]$. A positive value indicates that the distribution of the spatial agglomeration of the variable of interest is in a specific region with similar values; otherwise, it will follow the discrete distribution. If Moran's I value is close to zero, observed values are randomly distributed and have no relationship in space. As shown in Table 4, Moran's I values of carbon efficiency, manufacturing agglomeration, and high-end productive service agglomeration all meet the significance test at the $1 \%$ level, indicating that these variables have significant spatial dependencies. The low-end productive service passed the significance test for most years, but a small part of the living service industrial agglomeration degree passed the significance test. Therefore, the results showed that it is necessary to consider the spatial effects of industrial agglomeration on carbon efficiency.

In order to make up the lag of the released data in the official statistics and also to make the division of functional space between cities more convincing, in this part, we use the data from 2007 to 2016 and the fractional-order grey prediction model to forecast the data of the urban carbon efficiency and industrial agglomeration degree from 2017 to 2021 and measure the Moran value according to the prediction results (i.e., all the predictions for Moran's I index were calculated again based on the predicted data). The results show that the spatial correlation of carbon efficiency is expected to stabilize at a high level during 2017-2021 after experiencing the "high-low-high-low" fluctuation. For the 
TABLe 3: Sample statistics of carbon efficiency and other variables of Chinese cities.

\begin{tabular}{|c|c|c|c|c|}
\hline Variables & Mean & Std. dev. & Min. & Max. \\
\hline YC (GDP-carbon ratio, yuan/ton, 2010 price) & 23574.30 & 14808.54 & 1161.51 & 174833.01 \\
\hline MA (manufacturing agglomeration) & 0.8870 & 0.4917 & 0.0219 & 2.9114 \\
\hline LPSA (low-end productive service agglomeration) & 0.7066 & 0.3766 & 0.1065 & 2.7629 \\
\hline HPSA (high-end productive service agglomeration) & 0.8706 & 0.3262 & 0.2452 & 3.0570 \\
\hline LSA (living service agglomeration) & 0.8150 & 0.4335 & 0.1554 & 4.9674 \\
\hline LC (labor-carbon ratio, person/10,000 ton) & 762.92 & 549.61 & 34.83 & 6558.53 \\
\hline KC (capital-carbon ratio, yuan/ton, 2010 price) & 69842.46 & 55213.73 & 2733.59 & 722772.70 \\
\hline EC (energy-carbon ratio, $\mathrm{kW} \cdot \mathrm{h} / \mathrm{ton})$ & 786.00 & 336.84 & 118.30 & 9881.44 \\
\hline GOV (public finance income-GDP ratio, \%) & 7.2893 & 3.8857 & 0.4208 & 120.6395 \\
\hline FDI (foreign direct investment, 10,000 yuan, 2010 price) & 501408.20 & 1211010.00 & 106.28 & 20475308.20 \\
\hline
\end{tabular}

TABLE 4: Moran's I values.

\begin{tabular}{|c|c|c|c|c|c|}
\hline Year & $\mathrm{YC}$ & MA & LPSA & HPSA & LSA \\
\hline 2007 & $0.025^{* * *}$ & $0.102^{* * *}$ & $0.013^{* * *}$ & $0.012^{* * *}$ & 0.003 \\
\hline 2008 & $0.020^{* * *}$ & $0.104^{* * *}$ & $0.009^{* *}$ & $0.013^{* * *}$ & 0.003 \\
\hline 2009 & $0.017^{* * *}$ & $0.105^{* * *}$ & $0.005^{*}$ & $0.015^{* * *}$ & 0.001 \\
\hline 2010 & $0.022^{* * *}$ & $0.109^{* * *}$ & $0.005^{*}$ & $0.022^{* * *}$ & $0.005^{*}$ \\
\hline 2011 & $0.023^{* * *}$ & $0.100^{* * *}$ & $0.008^{* *}$ & $0.021^{* * *}$ & 0.002 \\
\hline 2012 & $0.014^{* * *}$ & $0.112^{* * *}$ & $0.010^{* *}$ & $0.021^{* * *}$ & $0.007^{* *}$ \\
\hline 2013 & $0.009^{* * *}$ & $0.129^{* * *}$ & 0.001 & $0.025^{* * *}$ & $0.006^{*}$ \\
\hline 2014 & $0.012^{* * *}$ & $0.133^{* * *}$ & -0.003 & $0.031^{* * *}$ & -0.001 \\
\hline 2015 & $0.016^{* * *}$ & $0.134^{* * *}$ & 0.000 & $0.036^{* * *}$ & 0.002 \\
\hline 2016 & $0.014^{* * *}$ & $0.133^{* * *}$ & -0.003 & $0.034^{* * *}$ & $0.009^{* *}$ \\
\hline 2017 & $0.021^{* * *}$ & $0.128^{* * *}$ & -0.001 & $0.033^{* * *}$ & $0.005^{*}$ \\
\hline 2018 & $0.020^{* * *}$ & $0.120^{* * *}$ & -0.001 & $0.033^{* * *}$ & $0.007^{* *}$ \\
\hline 2019 & $0.020^{* * *}$ & $0.111^{* * *}$ & 0.001 & $0.031^{* * *}$ & $0.008^{* *}$ \\
\hline 2020 & $0.019^{* * *}$ & $0.100^{* * *}$ & 0.002 & $0.030^{* * *}$ & $0.010^{* *}$ \\
\hline 2021 & $0.019^{* * *}$ & $0.089^{* * *}$ & 0.003 & $0.029^{* * *}$ & $0.010^{* * *}$ \\
\hline
\end{tabular}

Note. The symbols ${ }^{*},{ }^{* *}$, and ${ }^{* * *}$ represent significance levels at $10 \%, 5 \%$, and $1 \%$, respectively.

manufacturing and high-end productive service, which are of representative significance in the spatial division of urban labor, their Moran's I value continued to rise from 2007 to 2014. After reaching the maximum value in 2015 , both of them showed a decreasing trend in the following year. According to the results of fractional-order grey prediction, their spatial correlation decreased year by year from 2017 to 2021, which also well confirmed the changing trend. It is worth noting that the spatial correlation of the living service industry in each city gradually emerged, and its spatial correlation showed a stable upward trend from 2017 to 2021. The results give us the following implications. (1) In terms of the spatial correlation of carbon efficiency, except for carbon dioxide due to its natural characteristics, the economic correlation between cities is increasingly close. The carbon efficiency presents a "high-high" agglomeration trend in space, and the spatial correlation degree expressed by Moran's I values remains at a high level in the predicted years. (2) The essence of the spatial division of labor in urban agglomerations discussed above is that cities of different levels focus on the development of different industries. According to the Moran value of the predicted values, it can be found that the pattern of urban functional spatial division of labor still exists at the national level. Especially for manufacturing and high-end productive service, local government should choose industries with comparative advantages according to their development status and resource endowment, to form "staggered peak" development among cities. China's overall economic development will continue to advance in this development direction. (3) As a living service industry whose main function is to meet a number of necessary needs in residents' life, the development of this industry is highly correlated with urban economic conditions and residents' wealth. The increasing degree of spatial correlation of this industry year by year also proves that economic development among cities is more closely correlated.

4.3. Determination of Spatial Econometric Model. In order to accurately reflect the degree of spatial effects and the reasons for the spatial dependence, it is necessary to select a suitable spatial econometric model before doing the regression analysis. Referring to Elhorst [64], the method of "specific to general" was used in the preset study to identify the spatial econometric model (Table 5). First, the Lagrange multiplier (LM) tests were used to choose the spatial autoregressive model (SAR) or the spatial error model (SEM). If both LM_lag and R-LM_lag fail the significance test, we choose the SAR. If both LM_err and R_LM_err fail the significance test, we choose the SEM. In the present study, we rejected the SEM because both LM_err and R_LM_err passed the 
TABle 5: Tests of the spatial econometric model.

\begin{tabular}{lccc}
\hline Contents & Methods & Statistic value & $P$ value \\
\hline & LM_lag test & 138.865 & $\leq 0.01$ \\
SAR and SEM & LM_err test & 3274.995 & $\leq 0.01$ \\
& R-LM_lag test & 0.372 & 0.542 \\
& R-LM_err test & 3136.502 & $\leq 0.01$ \\
\hline \multirow{2}{*}{ Hausman test of SDM } & Hausman test & 5266.850 & $\leq 0.01$ \\
& Wald test & 333.270 & $\leq 0.01$ \\
Simplified test of SDM & & 173.850 & $\leq 0.01$ \\
\hline
\end{tabular}

significance tests. However, we could not choose the SAR on the condition that the LM_lag passed the significance test and the R-LM_lag failed the significance test. We need to determine whether the spatial Durbin model (SDM) could degenerate into SAR and SEM through performing the LR test and Wald test. Because both of these results significantly rejected the null hypothesis, we chose the SDM for the spatial econometric regression. Then, we performed a Hausman test to determine whether the model uses fixed or random effects. However, when calculating the variance inflation factor (VIF), we found that the addition of urban fixed effects would produce multicollinearity problem (VIF $>10$ ) among the explanatory variables (Table 6). Since the result of the Hausman test significantly rejected the null hypothesis, we used the time fixed spatial Durbin model.

4.4. Estimated Results of Spatial Econometric Model. According to Table 5, we chose the SDM with the time fixed effect to estimate equation (14). To take the robustness test, we also estimated OLS, SAR, SEM, and SLX with the time fixed effect (Table 7). Most explanatory variables passed the significance test, which indicated that the empirical data support the theoretical model and variables. Also, urban carbon efficiency is affected by both the endogenous and exogenous spatial interaction effects.

The spatial econometric model includes the interaction terms between the spatial weight matrix and the explained variables. It also includes the interaction terms between the spatial weight matrix and the explanatory variables. Consequently, the total effect includes two parts: the direct effect of the local area and the indirect effect caused by other areas (also known as spatial spillover effect). As the spatial spillover effect, the change of explanatory variables will cause the change of the carbon efficiency both in the local area and surrounding areas. Therefore, the change of carbon efficiency in surrounding areas will eventually cause the change of carbon efficiency in the local area owing to the feedback effect [65]. In other words, the change of the explanatory variables of city $i$ at time $t$ will not only have a direct impact on the explained variable of the city itself but also have an indirect impact on the explained variable of other cities (i.e., the adjacent areas of the city) and will eventually affect the area in turn (because for other areas, the area is also the "other area"). Therefore, considering the global effect in the spatial Durbin model, the coefficients of the explanatory
TABLe 6: Test of the fixed effects.

\begin{tabular}{lcc}
\hline Variables & $\begin{array}{c}\text { Fixed individual dummy variable } \\
\text { VIF value }\end{array}$ & $\begin{array}{c}\text { Fixed time dummy } \\
\text { variable } \\
\text { VIF value }\end{array}$ \\
\hline lnMA & 11.68 & 1.60 \\
lnLPSA & 5.40 & 1.63 \\
lnHPSA & 5.98 & 1.48 \\
lnLSA & 5.53 & 1.40 \\
$\operatorname{lnLC}$ & 8.39 & 3.42 \\
$\operatorname{lnKC}$ & 4.96 & 3.98 \\
$\operatorname{lnEC}$ & 3.06 & 1.19 \\
$\operatorname{lnGOV}$ & 3.56 & 1.34 \\
$\ln \mathrm{FDI}$ & 8.88 & 1.77 \\
\hline
\end{tabular}

variables only represent the direction and significance of their influences on the explained variable in the SDM model but do not reflect their actual marginal effects, which was raised as an issue by LeSage and Pace [66]. Accordingly, to solve the problem of the coefficients in the spatial econometric model being difficult to explain, we further separated the direct and indirect effects (Table 8). The direct effects contain the pure direct effects and the feedback effects on local carbon efficiency. The indirect effects contain the spatial impact of the explanatory variables from the surrounding areas on the local carbon efficiency, reflecting the spatial spillover effect.

As shown in Table 8, we found that the agglomeration effects of various industries showed significant heterogeneity. Thus, Hypothesis 1 is validated. The agglomeration of manufacturing industry and the agglomeration of highend productive services have significant impacts on the urban carbon efficiency. In addition, the impact of the high-end productive service is greater than that of the manufacturing industry, while the low-end productive services and living services have negative impacts on the urban carbon efficiency. Li et al. indicated that the greater demand for energy from fossil fuels of the manufacturing industry results in more $\mathrm{CO}_{2}$ emissions than other industries [67]. However, in the process of manufacturing industry agglomeration, the knowledge spillover, economies of scale of intermediate inputs, the information exchange among enterprises, and the multiple infrastructure construction will further promote carbon efficiency [29, $30,68]$. The impacts of segmented service industries showed significant heterogeneity. In the high-end 
TABLE 7: Estimation results of the spatial econometrics.

\begin{tabular}{|c|c|c|c|c|c|}
\hline Variables & OLS & SAR & SEM & SLX & SDM \\
\hline $\ln M A$ & $\begin{array}{c}0.0642^{* * *} \\
(8.67)\end{array}$ & $\begin{array}{c}0.0636^{* * *} \\
(8.56)\end{array}$ & $\begin{array}{c}0.0558^{* * *} \\
(7.46)\end{array}$ & $\begin{array}{c}0.0413^{* * *} \\
(5.29)\end{array}$ & $\begin{array}{c}0.0449^{* * *} \\
(5.86)\end{array}$ \\
\hline $\operatorname{lnLPSA}$ & $\begin{array}{c}-0.0168 \\
(-1.64)\end{array}$ & $\begin{array}{c}-0.0166 \\
(-1.63)\end{array}$ & $\begin{array}{c}-0.0217 \\
(-2.18)\end{array}$ & $\begin{array}{c}-0.0192^{*} \\
(-1.93)\end{array}$ & $\begin{array}{c}-0.0168^{*} \\
(-1.72)\end{array}$ \\
\hline $\operatorname{lnHPSA}$ & $\begin{array}{c}0.0771^{* * *} \\
(6.22)\end{array}$ & $\begin{array}{c}0.0779^{* * *} \\
(6.26)\end{array}$ & $\begin{array}{c}0.0841^{* * *} \\
(6.86)\end{array}$ & $\begin{array}{c}0.0917^{* * *} \\
(7.39)\end{array}$ & $\begin{array}{c}0.0954^{* * *} \\
(7.86)\end{array}$ \\
\hline $\operatorname{lnLSA}$ & $\begin{array}{c}-0.0489^{* * *} \\
(-4.71)\end{array}$ & $\begin{array}{c}-0.0491^{* * *} \\
(-4.73)\end{array}$ & $\begin{array}{c}-0.0453^{* * *} \\
(-4.38)\end{array}$ & $\begin{array}{c}-0.0324^{* * *} \\
(-3.25)\end{array}$ & $\begin{array}{c}-0.0323^{* * *} \\
(-3.10)\end{array}$ \\
\hline $\ln L C$ & $\begin{array}{c}0.3102^{* * *} \\
(30.48)\end{array}$ & $\begin{array}{c}0.3098^{* * *} \\
(30.44)\end{array}$ & $\begin{array}{c}0.3011^{* * *} \\
(29.34)\end{array}$ & $\begin{array}{c}0.3067^{* * *} \\
(29.37)\end{array}$ & $\begin{array}{c}0.2888^{* * *} \\
(27.27)\end{array}$ \\
\hline $\ln K C$ & $\begin{array}{c}0.5845^{* * *} \\
(58.92)\end{array}$ & $\begin{array}{c}0.5839^{* * *} \\
(58.31)\end{array}$ & $\begin{array}{c}0.5980^{* * *} \\
(59.34)\end{array}$ & $\begin{array}{c}0.5846^{* * *} \\
(57.24)\end{array}$ & $\begin{array}{c}0.6056^{* * *} \\
(57.75)\end{array}$ \\
\hline $\ln E C$ & $\begin{array}{c}0.0168 \\
(1.47)\end{array}$ & $\begin{array}{c}0.0156 \\
(1.35)\end{array}$ & $\begin{array}{l}0.0110 \\
(0.98)\end{array}$ & $\begin{array}{c}0.0171 \\
(1.51)\end{array}$ & $\begin{array}{c}0.0166 \\
(1.50)\end{array}$ \\
\hline $\operatorname{lnGOV}$ & $\begin{array}{c}-0.1449^{* * *} \\
(-13.78)\end{array}$ & $\begin{array}{c}-0.1449^{* * *} \\
(-13.78)\end{array}$ & $\begin{array}{c}-0.1424^{* * *} \\
(-13.47)\end{array}$ & $\begin{array}{c}-0.1459^{* * *} \\
(-13.48)\end{array}$ & $\begin{array}{c}-0.1328^{* * *} \\
(-12.16)\end{array}$ \\
\hline $\operatorname{lnFDI}$ & $\begin{array}{c}0.0431^{* * *} \\
(16.71)\end{array}$ & $\begin{array}{c}0.0430^{* * * *} \\
(16.64)\end{array}$ & $\begin{array}{c}0.0379^{* * *} \\
(13.97)\end{array}$ & $\begin{array}{c}0.0247^{* * *} \\
(8.15)\end{array}$ & $\begin{array}{c}0.0243^{* * *} \\
(8.16)\end{array}$ \\
\hline $\mathrm{W}^{*} \ln \mathrm{YC}$ & & $\begin{array}{c}0.0280 \\
(0.65)\end{array}$ & $\begin{array}{c}0.8810^{* * *} \\
(34.07)\end{array}$ & & $\begin{array}{c}0.7410^{* * *} \\
(22.95)\end{array}$ \\
\hline $\mathrm{W}^{*} \ln \mathrm{MA}$ & & & & $\begin{array}{c}0.2622^{* * *} \\
(4.52)\end{array}$ & $\begin{array}{c}0.1604^{* * *} \\
\quad(2.58)\end{array}$ \\
\hline $\mathrm{W}^{*} \ln L P S A$ & & & & $\begin{array}{c}0.0929 \\
(0.93)\end{array}$ & $\begin{array}{c}0.2920^{* *} \\
(2.48)\end{array}$ \\
\hline $\mathrm{W}^{*} \ln \mathrm{HPSA}$ & & & & $\begin{array}{c}-0.0475 \\
(-0.64)\end{array}$ & $\begin{array}{c}0.1181 \\
(0.88)\end{array}$ \\
\hline $\mathrm{W}^{*} \ln L S A$ & & & & $\begin{array}{c}-0.0936 \\
(-1.00)\end{array}$ & $\begin{array}{c}-0.0918 \\
(0.84)\end{array}$ \\
\hline $\mathrm{W}^{*} \ln L C$ & & & & $\begin{array}{r}-0.0775^{*} \\
(-1.88)\end{array}$ & $\begin{array}{c}0.1160 \\
(1.23)\end{array}$ \\
\hline $\mathrm{W}^{*} \ln \mathrm{KC}$ & & & & $\begin{array}{c}-0.1404^{* * *} \\
(-4.81)\end{array}$ & $\begin{array}{c}-0.9061^{* * *} \\
(-10.66)\end{array}$ \\
\hline $\mathrm{W}^{*} \ln \mathrm{EC}$ & & & & $\begin{array}{c}0.2639^{* * *} \\
(3.07)\end{array}$ & $\begin{array}{c}0.4451^{* * *} \\
(3.73)\end{array}$ \\
\hline $\mathrm{W}^{*} \ln \mathrm{GOV}$ & & & & $\begin{array}{c}-0.3234^{* * *} \\
(-4.16)\end{array}$ & $\begin{array}{c}-0.3823^{* * *} \\
(-3.36)\end{array}$ \\
\hline $\mathrm{W}^{*} \ln \mathrm{FDI}$ & & & & $\begin{array}{c}0.0900^{* * *} \\
(5.49)\end{array}$ & $\begin{array}{c}0.0620^{* * *} \\
(3.39)\end{array}$ \\
\hline $\log$-lik & 563.3508 & 563.5052 & 630.6464 & 663.2215 & 715.5981 \\
\hline$R^{2}$ & 0.8942 & 0.8976 & 0.8970 & 0.9045 & 0.9092 \\
\hline Observation & 2850 & 2850 & 2850 & 2850 & 2850 \\
\hline
\end{tabular}

Note. The symbols *, ${ }^{* *}$, and ${ }^{* * *}$ represent significance levels at $10 \%, 5 \%$, and $1 \%$, respectively; the values in parentheses are $t$ statistics; log-lik is log-likelihood.

productive service industry, the learning effect of knowledge spillover among enterprises, with the high added value of products, has brought significant improvements in efficiency. On the contrary, the agglomeration of the low-end productive service industries, such as transportation, warehousing and postal industry, and leasing and business service industry, cause an increase in direct energy consumption and "crowding effect" as bad as urban congestion and resource waste to worsen the urban carbon efficiency. Therefore, in order to achieve lowcarbon development, priority should be given to the highend productive service industry with the characteristics of knowledge- and capital-intensiveness.

The impacts of industrial agglomerations on carbon efficiency from neighboring areas, that is, the spatial spillover effect brought by urban industrial agglomeration, showed that all industries will have positive impacts on carbon efficiency. The impact of the high-end productive service industry is not significant, which shows that China is still in the early stage of industrial transformation. The highend productive service industry with a large service radius and small transaction frequency has not shown significant spatial spillover effects. The impact of the living service industry is not significant either, which indicated that the living service industry has the characteristic of a native service.

As for other explanatory variables, the direct effect coefficients of labor-carbon ratio, capital-carbon ratio, and energy-carbon ratio are significantly positive, noting that the improvement of efficiencies of input factors has significant positive effects on the improvement of carbon efficiency. The direct and indirect effects of FDI are both significantly 
TABLE 8: Direct and indirect effects of the SDM model.

\begin{tabular}{|c|c|c|}
\hline \multirow{2}{*}{ Explanatory variables } & \multicolumn{2}{|c|}{ Effects } \\
\hline & Direct effects & Indirect effects \\
\hline $\ln M A$ & $\begin{array}{c}0.0477^{* * *} \\
(6.05)\end{array}$ & $\begin{array}{c}0.7610^{* * *} \\
(3.05)\end{array}$ \\
\hline $\operatorname{lnLPSA}$ & $\begin{array}{c}-0.0128 \\
(-1.27)\end{array}$ & $\begin{array}{c}1.0955^{* *} \\
(2.30)\end{array}$ \\
\hline $\operatorname{lnHPSA}$ & $\begin{array}{c}0.0980^{* * *} \\
(8.06)\end{array}$ & $\begin{array}{c}0.7468 \\
(1.39)\end{array}$ \\
\hline $\operatorname{lnLSA}$ & $\begin{array}{c}-0.0316^{* * *} \\
(-3.15)\end{array}$ & $\begin{array}{l}0.2567 \\
(0.59)\end{array}$ \\
\hline $\operatorname{lnLC}$ & $\begin{array}{c}0.2931^{* * *} \\
(27.87)\end{array}$ & $\begin{array}{c}1.2854^{* * *} \\
(3.32)\end{array}$ \\
\hline $\ln \mathrm{KC}$ & $\begin{array}{c}0.5997^{* * *} \\
(57.50)\end{array}$ & $\begin{array}{c}-1.7800^{* * *} \\
(-4.71)\end{array}$ \\
\hline $\operatorname{lnEC}$ & $\begin{array}{c}0.0224^{* *} \\
(2.06)\end{array}$ & $\begin{array}{c}1.7800^{* * *} \\
\quad(3.41)\end{array}$ \\
\hline $\operatorname{lnGOV}$ & $\begin{array}{c}-0.1393^{* * *} \\
(-12.99)\end{array}$ & $\begin{array}{c}-1.8826^{* * *} \\
(-3.79)\end{array}$ \\
\hline $\operatorname{lnFDI}$ & $\begin{array}{c}0.0255^{* * *} \\
(8.69)\end{array}$ & $\begin{array}{c}0.3102^{* * * *} \\
(4.11)\end{array}$ \\
\hline
\end{tabular}

Note. The symbols ${ }^{*},{ }^{* *}$, and ${ }^{* * *}$ represent significance levels at $10 \%, 5 \%$, and $1 \%$, respectively; the values in parentheses are $t$ statistics; log-lik is log-likelihood.

positive, which shows that FDI plays a positive role in promoting China's economic development and shows that the "pollution heaven hypothesis" is not currently available for China [67]. The coefficient of $\operatorname{lnGOV}$ is significantly negative, which indicates that the government should not interfere too much in the economy. Otherwise, it will lead to an inefficiency of resource allocation and the "race to the bottom" in energy utilization, which will not be conducive to improving urban carbon efficiency.

4.5. The Effects of Industrial Agglomeration on Carbon Efficiency in a Megalopolis. At the level of the megalopolis, the agglomerations of manufacturing, high-end productive service, and living service industries all play important roles in promoting the urban carbon efficiency (Table 9), while the low-end productive service industry mainly has a negative impact on the carbon efficiency. Compared with the estimated results at the national level (Table 8), the manufacturing industry and the high-end industry have the same impact direction, but the degree of industrial agglomeration in promoting carbon efficiency in the megalopolis is significantly higher than that at the national level. The reason is that the spatial concentration of industries and population in a megalopolis improve the frequencies of knowledge spillover between manufacturing and service enterprises and reduce the transportation cost of goods exchanged between enterprises. They ultimately improve the efficiency of the economic operation and the efficiency of the energy utilization of the whole region. As far as the control variables are concerned, the direct effects of labor-carbon ratio, capital-carbon ratio, and energy-carbon ratio are significantly positive, while the direct effect of lnGOV is negative. This indicates that at both the national or level of the megalopolis, too much policy intervention will reduce carbon efficiency.
Comparing three large megalopolises, the direct effect of manufacturing agglomeration in the Yangtze River Delta is the largest, and the positive spatial spillover effect of manufacturing agglomeration in the Pearl River Delta is significantly greater than that in other megalopolises. In terms of the segmented service industry, the low-end productive service industry has no significant impact in the Circum-Bohai Sea Economic Zone. The direct effect in the Yangtze River Delta city group is significantly negative, and the indirect effect in the Pearl River Delta city group is significantly negative. The high-end productive service industry has a significant positive impact in each megalopolis, and the impact degrees are arranged by the Pearl River Delta, the Yangtze River Delta, and the Circum-Bohai Sea Economic Zone from large to small. All of the above are consistent with Hypothesis 2. It is worth noting that the spatial effect of high-end productive service agglomeration in the Pearl River Delta megalopolis is far greater than other megalopolises, which provides a good example for the development of megalopolis.

We know that the manufacturing industry is inclined to be located near to the cities with productive services [69], while there also exists a "crowding out" effect between the manufacturing and service industries [70]. We further analyzed the trend of the ratio of the employment number in central cities (municipalities, subprovincial cities, and provincial capital cities) in megalopolises to measure the level of the division of labor. As shown in Figure 5, the employment proportion of high-end productive service increased in the central cities but that of manufacturing and low-end productive service decreased year by year, which partially confirm Hypothesis 3. Therefore, the central cities tend to cultivate the high-end productive service industry and gradually become "technology pools" and "market areas" for improving carbon efficiency of themselves and surrounding areas. 
TABLE 9: Direct and indirect effects of the SDM model in three megalopolises.

\begin{tabular}{|c|c|c|c|c|c|c|}
\hline \multirow[t]{2}{*}{ Explanatory variables } & \multicolumn{2}{|c|}{$\begin{array}{c}\text { Circum-Bohai Sea Economic } \\
\text { Zone }\end{array}$} & \multicolumn{2}{|c|}{ Yangtze River Delta Megalopolis } & \multicolumn{2}{|c|}{ Pearl River Delta Megalopolis } \\
\hline & Direct effect & Indirect effect & Direct effect & Indirect effect & Direct effect & Indirect effect \\
\hline $\ln M A$ & $\begin{array}{l}0.0824^{* * *} \\
(4.21)\end{array}$ & $\begin{array}{l}0.3533^{* * *} \\
(3.53)\end{array}$ & $\begin{array}{l}0.1700^{* * *} \\
(3.96)\end{array}$ & $\begin{array}{c}0.9558^{* *} \\
(2.13)\end{array}$ & $\begin{array}{c}0.0540 \\
(0.81)\end{array}$ & $\begin{array}{l}2.4513^{* * *} \\
(3.85)\end{array}$ \\
\hline $\operatorname{lnLPSA}$ & $\begin{array}{c}0.0090 \\
(0.49)\end{array}$ & $\begin{array}{c}-0.0819 \\
(-0.87)\end{array}$ & $\begin{array}{c}-0.0699^{* *} \\
(-2.10)\end{array}$ & $\begin{array}{c}-0.2967 \\
(-1.09)\end{array}$ & $\begin{array}{c}-0.0554 \\
(-1.15)\end{array}$ & $\begin{array}{c}-0.7830^{* *} \\
(-2.88)\end{array}$ \\
\hline lnHPSA & $\begin{array}{l}0.0747^{* * *} \\
(2.84)\end{array}$ & $\begin{array}{c}0.0118 \\
(0.10)\end{array}$ & $\begin{array}{l}0.1978^{* * *} \\
(3.60)\end{array}$ & $\begin{array}{c}-0.4740 \\
(-0.79)\end{array}$ & $\begin{array}{l}0.4088^{* * *} \\
(5.04)\end{array}$ & $\begin{array}{c}2.2624^{* * *} \\
(4.88)\end{array}$ \\
\hline $\operatorname{lnLSA}$ & $\begin{array}{c}0.0570^{*} \\
(1.93)\end{array}$ & $\begin{array}{c}0.2721^{* *} \\
(2.62)\end{array}$ & $\begin{array}{c}0.0329 \\
(0.70)\end{array}$ & $\begin{array}{r}0.9612^{*} \\
(2.05)\end{array}$ & $\begin{array}{c}0.0880^{* *} \\
(2.31)\end{array}$ & $\begin{array}{c}0.6404^{* *} \\
(2.82)\end{array}$ \\
\hline $\operatorname{lnLC}$ & $\begin{array}{l}0.2555^{* * *} \\
(8.39)\end{array}$ & $\begin{array}{c}-0.6340^{* * *} \\
(-3.54)\end{array}$ & $\begin{array}{l}0.4077^{* * *} \\
(11.30)\end{array}$ & $\begin{array}{l}0.9400^{* * *} \\
(2.91)\end{array}$ & $\begin{array}{l}0.3041^{* * *} \\
(6.29)\end{array}$ & $\begin{array}{c}0.5630^{* *} \\
(2.45)\end{array}$ \\
\hline $\ln K C$ & $\begin{array}{l}0.5859^{* * *} \\
(22.81)\end{array}$ & $\begin{array}{c}0.3367^{* *} \\
(2.53)\end{array}$ & $\begin{array}{c}0.5403^{* * *} \\
(14.26)\end{array}$ & $\begin{array}{r}0.1373 \\
(0.57)\end{array}$ & $\begin{array}{c}0.6311^{* * *} \\
(14.04)\end{array}$ & $\begin{array}{c}0.7830^{* *} \\
(2.73)\end{array}$ \\
\hline $\operatorname{lnEC}$ & $\begin{array}{l}0.1922^{* * *} \\
(3.89)\end{array}$ & $\begin{array}{l}0.6959^{* * *} \\
(3.17)\end{array}$ & $\begin{array}{l}0.1319^{* * *} \\
\quad(3.42)\end{array}$ & $\begin{array}{l}1.0999^{* * *} \\
(3.32)\end{array}$ & $\begin{array}{c}0.1133^{* *} \\
(2.52)\end{array}$ & $\begin{array}{c}-1.7118^{* * *} \\
(-4.79)\end{array}$ \\
\hline $\operatorname{lnGOV}$ & $\begin{array}{c}-0.1336^{* * *} \\
(-4.65)\end{array}$ & $\begin{array}{l}0.2348^{* * *} \\
(2.76)\end{array}$ & $\begin{array}{c}-0.2877^{* * *} \\
(-4.78)\end{array}$ & $\begin{array}{c}0.0798 \\
(0.15)\end{array}$ & $\begin{array}{c}-0.3571^{* * *} \\
(-6.47)\end{array}$ & $\begin{array}{c}-0.0075 \\
(-0.02)\end{array}$ \\
\hline $\operatorname{lnFDI}$ & $\begin{array}{c}0.0137^{* *} \\
(2.28)\end{array}$ & $\begin{array}{c}-0.0188 \\
(-1.17)\end{array}$ & $\begin{array}{c}0.0188 \\
(1.45)\end{array}$ & $\begin{array}{c}-0.1689 \\
(-1.37)\end{array}$ & $\begin{array}{c}0.1440^{* * *} \\
(10.65)\end{array}$ & $\begin{array}{c}0.3523^{* * *} \\
(3.04)\end{array}$ \\
\hline
\end{tabular}

Note. The symbols ${ }^{*},{ }^{* *}$, and ${ }^{* * *}$ represent significance levels at $10 \%, 5 \%$, and $1 \%$, respectively; the values in parentheses are $t$ statistics; log-lik is log-likelihood.

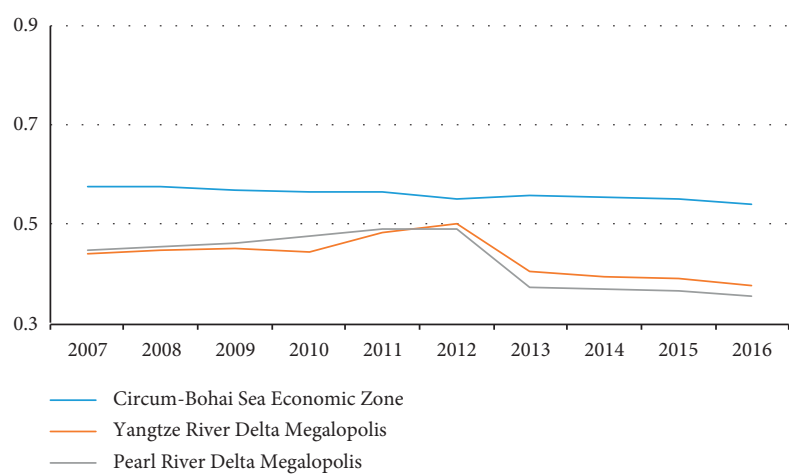

(a)

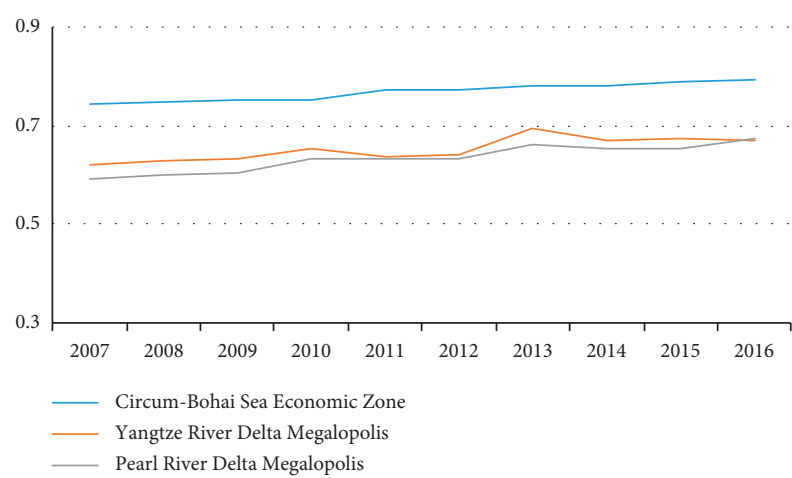

(c)

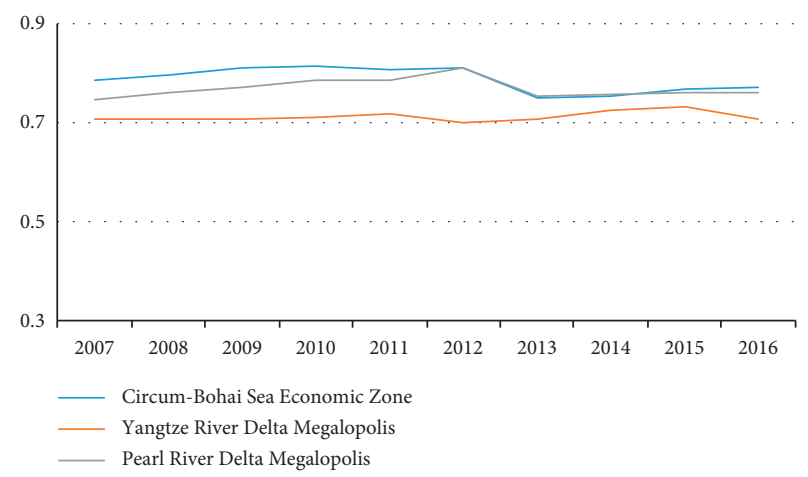

(b)

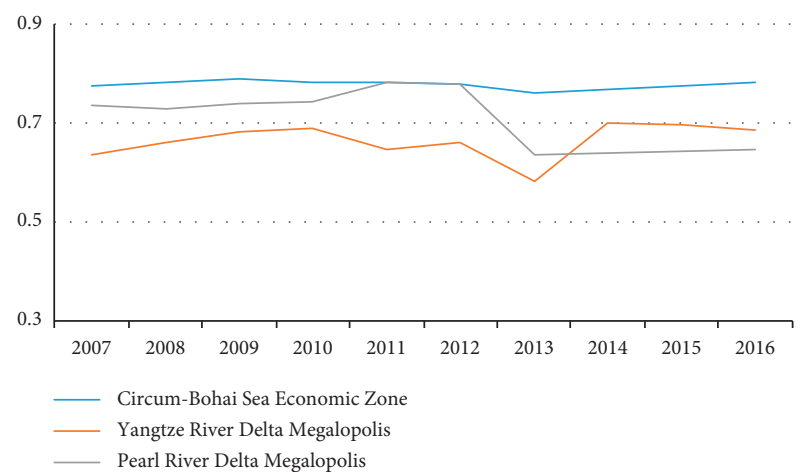

(d)

Figure 5: The ratio of employees of central cities to other cities in three megalopolises from 2007 to 2016. (a) Manufacturing industry. (b) Low-end productive service industry. (c) High-end productive service industry. (d) Living service industry.

The common cities are inclined to develop their manufacturing industry with complementary functions for neighboring areas. Therefore, the divisions of labor for central and common cities in the megalopolis are coupled with the industrial agglomeration for improving carbon efficiency. 


\section{Conclusion}

There are two constraints on China's economic development: economic growth and the control of $\mathrm{CO}_{2}$ emissions. In the present study, we used the spatial econometric method to explore the impact of industrial agglomeration on carbon efficiency with panel data of 285 cities above prefecture level and three megalopolises in China, for the period 2007-2016. The results showed the following. (1) At the national level, all industrial agglomerations, except the living service industry, take positive roles in improving the urban carbon efficiency, and the impact from low-end productive service agglomeration mainly comes from the spatial spillover effect. (2) Comparing the industrial agglomerations of the whole country and the megalopolises, we found that manufacturing industry, high-end productive service industry, and living service industry of each megalopolis have significant influences on the urban carbon efficiency, and the influences are greater than the average national level. (3) In the three megalopolises, manufacturing agglomeration, high-end productive service agglomeration, and living service agglomeration all significantly improve carbon efficiency. The impacts of manufacturing agglomeration and high-end productive service agglomeration on carbon efficiency are ranked from large to small in the order of the Pearl River Delta, the Yangtze River Delta, and the Circum-Bohai Sea Economic Zone. The low-end productive service agglomerations in the Yangtze River Delta and Pearl River Delta have negative effects on carbon efficiency with the crowding effect.

Accordingly, we propose several policy implications.

The empirical examination showed that manufacturing agglomeration and high-end productive service agglomeration improve carbon efficiency in the city itself and surrounding cities. With the purpose of keeping stable economic growth and reducing $\mathrm{CO}_{2}$ emissions, the Chinese government should "unbound" the factor market and establish a "common market" between cities and release the "institutional dividend" through breaking down administrative barriers and regional trade protectionism. According to the heterogeneity of the industrial agglomeration effects, the government should accord priority to specific industries from the perspective of regional comparative advantages. It should avoid the excessive pursuit of industrial advancement in the competition of cities, especially the "comparison and pursuit" for the development of high-end productive service industry among cities.

At the level of megalopolises, compared with the national level, the agglomerations of manufacturing and highend productive service have greater impacts on carbon efficiency. The central cities have more chances to obtain institutional and policy priority and should cultivate diversified high-end productive service industries as well as become the "technology pool" and "market area" for improving carbon efficiency in native and surrounding areas. Since the manufacturing and low-end productive service industries are more dependent on savings on production costs and improvement of transaction efficiency, the common cities should form complementary functions for central cities and make the coordinated development of manufacturing and low-end productive services.

\section{Data Availability}

The original data sources were the China City Statistical Yearbook, China Energy Statistics Yearbook, and Beijing Shu Huitong Environmental Technology Research Institute Data Service Network (http://www.3edata.com).

\section{Conflicts of Interest}

The authors declare that they have no conflicts of interest.

\section{Acknowledgments}

This study was supported by the National Natural Science Foundation of China (grant no. 71704095) (a study on regional air pollutant emission reduction target, step-by-step benchmark path and technical prediction based on environmental production technology) and Young Scholars Program of Shandong University, Weihai.

\section{References}

[1] IEA, World Energy Outlook 2008, https://www.iea.org/ reports/world-energy-outlook-2008, International Energy Agency, Paris, France, 2008, https://www.iea.org/reports/ world-energy-outlook-2008.

[2] World Bank, Carbon Dioxide Emission Open Data 2014, World Bank Group, Washington D.C., USA, 2014, https://data. worldbank.org/indicator/EN.ATM.CO2E.KT?view=chart.

[3] Z. Mi, Y. Zhang, D. Guan et al., "Consumption-based emission accounting for Chinese cities," Applied Energy, vol. 184, no. 12, pp. 1073-1081, 2016.

[4] H.-L. Lin, H.-Y. Li, and C.-H. Yang, "Agglomeration and productivity: Firm-level evidence from China's textile industry," China Economic Review, vol. 22, no. 3, pp. 313-329, 2011.

[5] B. B. Yu, "Economic growth effects of industrial restructuring and productivity improvement-—analysis of dynamic spatial panel model with Chinese city data," China Industrial Economics, vol. 34, no. 12, pp. 83-98, 2015.

[6] Y. M. Liang and M. J. Dong, "Sources of China's economic growth: an analysis based on nonparametric accounting method," China Economist, vol. 12, no. 3, pp. 78-93, 2017.

[7] M. A. Cole, R. J. R. Elliott, and S. Wu, "Industrial activity and the environment in China: an industry-level analysis," China Economic Review, vol. 19, no. 3, pp. 393-408, 2008.

[8] A. Otsuka, M. Goto, and T. Sueyoshi, "Energy efficiency and agglomeration economies: the case of Japanese manufacturing industries," Regional Science Policy \& Practice, vol. 6, no. 2, pp. 195-212, 2014.

[9] J. Li and Z. Cheng, "Study on total-factor carbon emission efficiency of China's manufacturing industry when considering technology heterogeneity," Journal of Cleaner Production, vol. 260, no. 7, Article ID 121021, 2020.

[10] G. Wang, X. Deng, J. Wang, F. Zhang, and S. Liang, "Carbon emission efficiency in China: a spatial panel data analysis," China Economic Review, vol. 56, Article ID 101313, 2019.

[11] C. Sun, Z. Li, T. Ma, and R. He, "Carbon efficiency and international specialization position: evidence from global value 
chain position index of manufacture," Energy Policy, vol. 128, pp. 235-242, 2019.

[12] N. Zhang, F. Kong, Y. Choi, and P. Zhou, "The effect of sizecontrol policy on unified energy and carbon efficiency for Chinese fossil fuel power plants," Energy Policy, vol. 70, pp. 193-200, 2014.

[13] S. Wang and Y. Ma, "Influencing factors and regional discrepancies of the efficiency of carbon dioxide emissions in Jiangsu, China," Ecological Indicators, vol. 90, pp. 460-468, 2018.

[14] Y. Wang, F. Duan, X. Ma, and L. He, "Carbon emissions efficiency in China: key facts from regional and industrial sector," Journal of Cleaner Production, vol. 206, pp. 850-869, 2019.

[15] F. Zhang, X. Deng, F. Phillips, C. Fang, and C. Wang, "Impacts of industrial structure and technical progress on carbon emission intensity: evidence from 281 cities in China," Technological Forecasting and Social Change, vol. 154, p. 119949, 2020.

[16] Q. Wang, B. Su, P. Zhou, and C.-R. Chiu, "Measuring totalfactor $\mathrm{CO}_{2}$ emission performance and technology gaps using a non-radial directional distance function: A modified approach," Energy Economics, vol. 56, no. 5, pp. 475-482, 2016.

[17] Q. Wang, Y. Hang, J.-L. Hu, and C.-R. Chiu, "An alternative metafrontier framework for measuring the heterogeneity of technology," Naval Research Logistics (NRL), vol. 65, no. 5, pp. 427-445, 2018.

[18] C. L. Fang and D. Yu, China's New Urbanization: Developmental Paths, Blueprints and Patterns, Science Press, Beijing, China, 2016.

[19] J. Virkanen, "Effect of urbanization on metal deposition in the bay of Töölönlahti, Southern Finland," Marine Pollution Bulletin, vol. 36, no. 9, pp. 729-738, 1998.

[20] E. Verhoef and P. Nijkamp, "Urban environmental externalities, agglomeration forces, and the technological "Deus ex Machina", Environment and Planning A: Economy and Space, vol. 40, no. 4, pp. 928-947, 2008.

[21] A. Frank, N. Moussiopoulos, P. Sahm et al., "Urban air quality in larger conurbations in the European Union," Environmental Modelling \& Software, vol. 16, no. 4, pp. 399-414, 2001.

[22] T. A. Duc, G. Vachaud, M. P. Bonnet et al., "Experimental investigation and modelling approach of the impact of urban wastewater on a tropical river: a case study of the Nhue River, Hanoi, Viet Nam," Journal of Hydrology, vol. 334, no. 3, pp. 347-358, 2007.

[23] M. E. Poter, "Clusters and the new economics of competition," Harvard Business Review, vol. 11, pp. 77-90, 1998.

[24] P. Krugman, "Space: The final frontier," Journal of Economic Perspectives, vol. 12, no. 2, pp. 161-174, 1998.

[25] M. Fujita and J. F. Thisse, Economics of Agglomeration: Cities, Industrial Location, and Regional Growth, Cambridge University Press, Cambridge, UK, 2002.

[26] M. Hosoe and T. Naito, "Trans-boundary pollution transmission and regional agglomeration effects*," Papers in Regional Science, vol. 85, no. 1, pp. 99-120, 2006.

[27] Q. Su, "The effect of population density, road network density, and congestion on household gasoline consumption in U.S. urban areas," Energy Economics, vol. 33, no. 3, pp. 445-452, 2011.

[28] F. Han, P. Feng, and L. G. Yang, "Spatial agglomeration effects of China's cities and industrial energy efficiency," China Population Resources and Environment, vol. 24, no. 05, pp. 72-79, 2014.
[29] F. Han, R. Xie, Y. Lu et al., "The effects of urban agglomeration economies on carbon emissions: evidence from Chinese cities," Journal of Cleaner Production, vol. 172, pp. 1096-1110, 2018.

[30] L. J. Zhang, P. J. Rong, Y. C. Qin et al., "Does industrial agglomeration mitigate fossil $\mathrm{CO}_{2}$ emissions? an empirical study with spatial panel regression model," Energy Procedia, vol. 152, pp. 731-737, 2018.

[31] N. Shen, R. M. Deng, and Q. W. Wang, "Influence of agglomeration of manufacturing and the producer service sector on energy efficiency," Polish Journal of Environmental Studies, vol. 28, no. 5, pp. 14-31, 2019.

[32] W. Jacobs, H. R. A. Koster, and F. Van Oort, "Co-agglomeration of knowledge-intensive business services and multinational enterprises," Journal of Economic Geography, vol. 14, no. 2, pp. 443-476, 2014.

[33] Y. Huang, L. Li, and Y. T. Yu, "Does urban cluster promote the increase of urban eco-efficiency? evidence from Chinese cities," Journal of Cleaner Production, vol. 197, pp. 957-971, 2018.

[34] W. C. Yue, Y. P. Cai, Z. F. Yang et al., "Structural optimization for industrial sectors to achieve the targets of energy intensity mitigation in the urban cluster of the Pearl River Delta," Ecological Indicators, vol. 95, pp. 673-686, 2018.

[35] L. Chen, L. Y. Xu, and Z. F. Yang, "Accounting carbon emission changes under regional industrial transfer in an urban agglomeration in China's Pearl River Delta," Journal of Cleaner Production, vol. 167, pp. 110-119, 2017.

[36] Y. M. Li, L. Y. Sun, H. L. Zhang et al., "Does industrial transfer within urban agglomerations promote dual control of total energy consumption and energy intensity?" Journal of Cleaner Production, vol. 204, pp. 607-617, 2018.

[37] H. J. Xiao, Y. L. Shan, N. Zhang et al., "Comparisons of $\mathrm{CO}_{2}$ emission performance between secondary and service industries in Yangtze River Delta cities," Journal of Environmental Management, vol. 252, pp. 109-136, 2019.

[38] J. Friedman, Regional Development Policy: A Case Study of Venezuel, MIT Press, Cambridge, UK, 1966.

[39] J. V. Henderson, "The sizes and types of cities," American Economic Review, vol. 64, no. 4, pp. 55-69, 1974.

[40] X. Deng, J. Huang, S. Rozelle et al., "Economic growth and the expansion of urban land in China," Urban Studies, vol. 47, no. 4, pp. 813-843, 2010.

[41] J. J. Zheng, P. Jiang, W. Qiao et al., "Analysis of air pollution reduction and climate change mitigation in the industry sector of Yangtze River Delta in China," Journal of Cleaner Production, vol. 114, pp. 314-322, 2016.

[42] Q. M. Yuan and A. Z. Zhang, "Research on the present situation of coordinated development and the innovation path of Beijing-Tianjin-Hebei industry," in Proceedings of the 2015 3rd International Conference on Education, Management, Arts, Economics and Social Science, pp. 1358-1361, Atlantis Press, Paris, France, July 2016.

[43] X. Yu, Z. Y. Wu, H. R. Zheng et al., "How urban agglomeration improve the emission efficiency? a spatial econometric analysis of the Yangtze River Delta urban agglomeration in China," Journal of Environmental Management, vol. 260, pp. 110-132, 2020.

[44] B. Q. Liu, C. Tian, Y. Q. Li et al., "Research on the effects of urbanization on carbon emissions efficiency of urban agglomerations in China," Journal of Cleaner Production, vol. 197, pp. 1374-1381, 2018.

[45] S. J. Wang, J. Y. Zeng, Y. Y. Huang et al., "The effects of urbanization on $\mathrm{CO}_{2}$ emissions in the Pearl River Delta: a 
comprehensive assessment and panel data analysis," Applied Energy, vol. 228, pp. 1693-1706, 2018.

[46] Q. Xu, Y. X. Dong, and R. Yang, "Urbanization impact on carbon emissions in the Pearl River Delta region: Kuznets curve relationships," Journal of Cleaner Production, vol. 180, pp. 514-523, 2018.

[47] X. L. Ouyang, X. Y. Mao, C. W. Sun et al., "Industrial energy efficiency and driving forces behind efficiency improvement: evidence from the Pearl River Delta urban agglomeration in China," Journal of Cleaner Production, vol. 220, pp. 899-909, 2019.

[48] J. B. Li, X. J. Huang, H. Yang et al., "Convergence of carbon intensity in the Yangtze River Delta, China," Habitat International, vol. 60, pp. 58-68, 2017.

[49] R. Xie, J. R. Fang, and C. J. Liu, "The effects of transportation infrastructure on urban carbon emissions," Applied Energy, vol. 196, pp. 199-207, 2017.

[50] E. L. Glaeser and M. E. Kahn, "The greenness of cities: carbon dioxide emissions and urban development," Journal of Urban Economics, vol. 67, no. 3, pp. 404-418, 2010.

[51] H. Q. Li, Y. Lu, J. Zhang et al., "Trends in road freight transportation carbon dioxide emissions and policies in China," Energy Policy, vol. 57, pp. 99-106, 2013.

[52] S. T. Li and H. X. Li, "On the characteristics and evolution trends of the distribution pattern of service industries," Industrial Economics Research, vol. 5, pp. 1-10, 2014.

[53] H. Y. Lu, Research on the Development Mode and Supply Policy of Service Industry from the Perspective of Dual Upgrading of Industry and Consumption, China Commerce and Trade Press, Beijing, China, 2016.

[54] Y. Xuan and Y. Z. Yu, "Hierarchical division of productive service industry and manufacturing efficiency-empirical study based on 38 cities in Yangtze River Delta region," Industrial Economics Research, vol. 3, pp. 1-10, 2014.

[55] L. F. Wu, S. Liu, L. Yao et al., "Grey system model with the fractional order accumulation," Communications in Nonlinear Science Numerical Simulation, vol. 18, no. 7, pp. 17751785, 2013.

[56] M. S. Yin and H. Tang, "On the fit and forecasting performance of grey prediction models for China's labor formation," Mathematical and Computer Modelling, vol. 57, no. 3-4, pp. 357-365, 2013.

[57] C. Yan, L. F. Wu, L. Y. Liu et al., "Fractional Hausdorff grey model and its properties," Chaos, Solitons \& Fractals, vol. 138, no. 9, Article ID 109915, 2020.

[58] Z. Griliches, "Issues in assessing the contribution of research and development to productivity growth," Bell Journal Economy, vol. 10, pp. 92-116, 1979.

[59] F. Shi and K. R. Shen, "Government intervention, economic agglomeration and energy efficiency," Management World, vol. 10, pp. 6-18, 2013.

[60] F. Han, R. Xie, and J. Y. Fang, "Urban agglomeration economies and industrial energy efficiency," Energy, vol. 162, pp. 45-59, 2018.

[61] S. Z. Ke, "Agglomeration, productivity, and spatial spillovers across Chinese cities," The Annals of Regional Science, vol. 45, no. 1, pp. 157-179, 2010.

[62] F. Han and S. Ke, "The effects of factor proximity and market potential on urban manufacturing output," China Economic Review, vol. 39, pp. 31-45, 2016.

[63] C. Ertur and K. W. Growth, "Growth, technological interdependence and spatial externalities: theory and evidence," Applied Economic, vol. 22, no. 6, pp. 1033-1062, 2007.
[64] J. P. Elhorst, "Matlab software for spatial panels," International Regional Science Review, vol. 37, no. 1, pp. 197-206, 2014.

[65] S. Shao, X. Li, J. H. Cao et al., "The choice of economic policy for haze pollution control in China-based on the perspective of spatial spillover effect," Economic Research, vol. 51, no. 9, pp. 73-88, 2016.

[66] J. Lesage and R. K. Pace, Introduction to Spatial Econometrics, Chapman and Hall/CRC, London, UK, 2009.

[67] L. Li, Y. L. Lei, S. M. Wu et al., "Impacts of city size change and industrial structure change on $\mathrm{CO}_{2}$ emissions in Chinese cities," Journal of Cleaner Production, vol. 195, pp. 831-838, 2018.

[68] D. K. Chen, S. Y. Chen, and H. Jin, "Industrial agglomeration and $\mathrm{CO}_{2}$ emissions: evidence from 187 Chinese prefecturelevel cities over 2005-2013," Journal of Cleaner Production, vol. 172, pp. 993-1003, 2018.

[69] S. Z. Ke, M. He, and C. H. Yuan, "Synergy and co-agglomeration of producer services and manufacturing: a panel data analysis of Chinese cities," Regional Studies: The Journal of the Regional Studies Association, vol. 48, no. 11, pp. 1829-1841, 2014.

[70] F. Tregenna, "The contributions of manufacturing and services to employment creation and growth in South Africa," South African Journal of Economics, vol. 76, p. 175, 2008. 